\title{
Expectations, Means-Tested Subsidies, and Economic Performance during the Recession
}

\author{
Casey B. Mulligan \\ Department of Economics, University of Chicago, Chicago, IL, USA \\ Email: c-mulligan@uchicago.edu
}

How to cite this paper: Mulligan, C.B. (2017) Expectations, Means-Tested Subsidies, and Economic Performance during the Recession. Journal of Mathematical Finance, 7, 536-570.

https://doi.org/10.4236/jmf.2017.73029

Received: May 2, 2017

Accepted: July 9, 2017

Published: July 12, 2017

Copyright $\odot 2017$ by author and Scientific Research Publishing Inc. This work is licensed under the Creative Commons Attribution International License (CC BY 4.0).

http://creativecommons.org/licenses/by/4.0/

\section{(c) (i) Open Access}

\begin{abstract}
The aggregate neoclassical growth model with only one impulse-meanstested subsidies whose replacement rates began rising at the end of 2007produces time series for aggregate labor usage, consumption, investment, and real GDP that closely resemble actual US time series. Despite having no explicit financial market, the model has investment fall steeply during the recession not because of any distortions with the supply of capital, but merely because labor is falling and labor is complementary with capital in the production function. Through the lens of the model, the fact that real consumption fell significantly below trend during 2008 suggests that market participants were expecting labor usage to remain depressed for several years to come.
\end{abstract}

\section{Keywords}

Labor Market, Means-Tested Subsidies, Recession, Neoclassical Growth Model

\section{Introduction}

In 2008-2009, the market economies of the US and other countries dramatically cut back their labor usage. Roughly coincident with the collapse of labor usage was a crisis in financial markets. Was the financial crisis a reaction to, and anticipation of, the labor collapse? Or did the financial crisis create unemployment? Answers to these questions are important because they go to the heart of the recession's causes, and speak to the role of government in affecting the economy's path.

Limiting the supply of aggregate investment is a mechanism for financial markets to impact the rest of the economy, and in fact real investment fell through the first year and a half of the recession. In this case, a notable effect of financial crisis would be to reduce aggregate investment below (and increase 
consumption above) what is efficient given the labor employed. Alternatively, financial crisis or something else could reduce labor usage more directly, and, given the complementarity of labor and capital in production, investment would respond to put the capital stock on a path that is consistent with the lesser amount of labor usage. To contribute to the bigger questions posed above, this paper considers whether a single "distortionary" or "wedge" shock (akin to a change in the rate of labor income taxation) to the labor market in a simple aggregate model-without explicit financial markets-would produce dynamics that resemble this recession's measured dynamics and, if so, how such a "labor wedge" recession would end. The results offer one barometer for gauging the relative importance of various explanations for the actual recession.

The aggregate implications of shocks to the labor market are interesting in their own right given the history of business cycles, and the emergence during this recession of a number of public and private sector actions that are expected to distort the labor market. The Great Depression of the 1930's cannot be entirely attributed to a labor wedge, but [1] makes the case that a peaking of union influence was an important factor. Some recessions are associated with little, if any, labor wedge, but an extensive labor wedge literature beginning with [2] and as recent as [3] emphasize the significance of labor wedges over several previous business cycles ${ }^{1}$.

During the 2008-9 recession, a variety of private and public sector actions emerged that would likely distort the labor market. The federal minimum wage was hiked three times. Labor market search frictions were arguably greater than usual. Prices fell, and perhaps wages did not fall commensurately. A large number of homeowners owed more on their mortgage than their house was worth, and both private and public sector renegotiations of the mortgage contracts have served as a massive implicit tax on earning during the recession because borrowers can expect their earnings to affect the amount that lenders will forgive [6]. Renegotiations of business debts [7], consumer loans [8], student loans, and tax debts present debtors with similar disincentives. A new home buyers' $\$ 8000$ tax credit was made available, but phased out as annual family income varied from $\$ 80,000$ to $\$ 120,000$. Other parts of the 2009 "stimulus law" increased the generosity of mean-tested subsidies like food stamps, and employment-tested subsidies like unemployment insurance. Congress considered various legislation that would raise marginal income tax rates, and would present Americans with new health benefits that would be phased out with employment and income.

The quantitative incentive effects of many, if not all, of these events are complex and varied, and might therefore seem beyond the reach of aggregate analysis. My approach here is to (a) select the large subset of these events that can be characterized as income- and employment-tested transfers either from the government or from lenders, and model their combination as a single subsidy program whose aggregate expenditure closely follows the combined expenditure of the actual subsidy programs and (b) model the labor supply of persons ineligible

${ }^{1}$ See also [4], [5], and further references cited below. 
for the subsidies separately from the labor supply of the rest of the population, recognizing the two groups would likely supply different amounts of labor even in the absence of subsidies, and that the causality between subsidies and labor market outcomes is in both directions. My approach has the potential dangers that two groups might not be enough to capture the heterogeneity in the actual population, and that the programs selected for analysis are either not inclusive enough-some omitted programs also push incentives in the same direction as the included ones-or too inclusive because some parts of them might not be means-tested. Nevertheless, the results can suggest whether or not the combination of several means-tested subsidy programs were a major factor affecting employment and other aggregate outcomes.

Figure 1 displays inflation-adjusted quarterly time series for six types of means-tested personal receipts by non-elderly households: the value of in-kind receipts from the Medicaid health insurance program, cash receipts from unemployment insurance, receipts from the Supplemental Nutrition Assistance Program (SNAP), receipts from other means-tested government transfer programs ${ }^{2}$, "home retention actions" (that is, loan modifications, short sales, and deeds-inlieu of foreclosure), and consumer loan charge-offs by commercial banks. Before the recession, housing-price collapse, and expansion of means-tested programs, the combination of these benefits was only about $\$ 250$ billion (constant dollars)

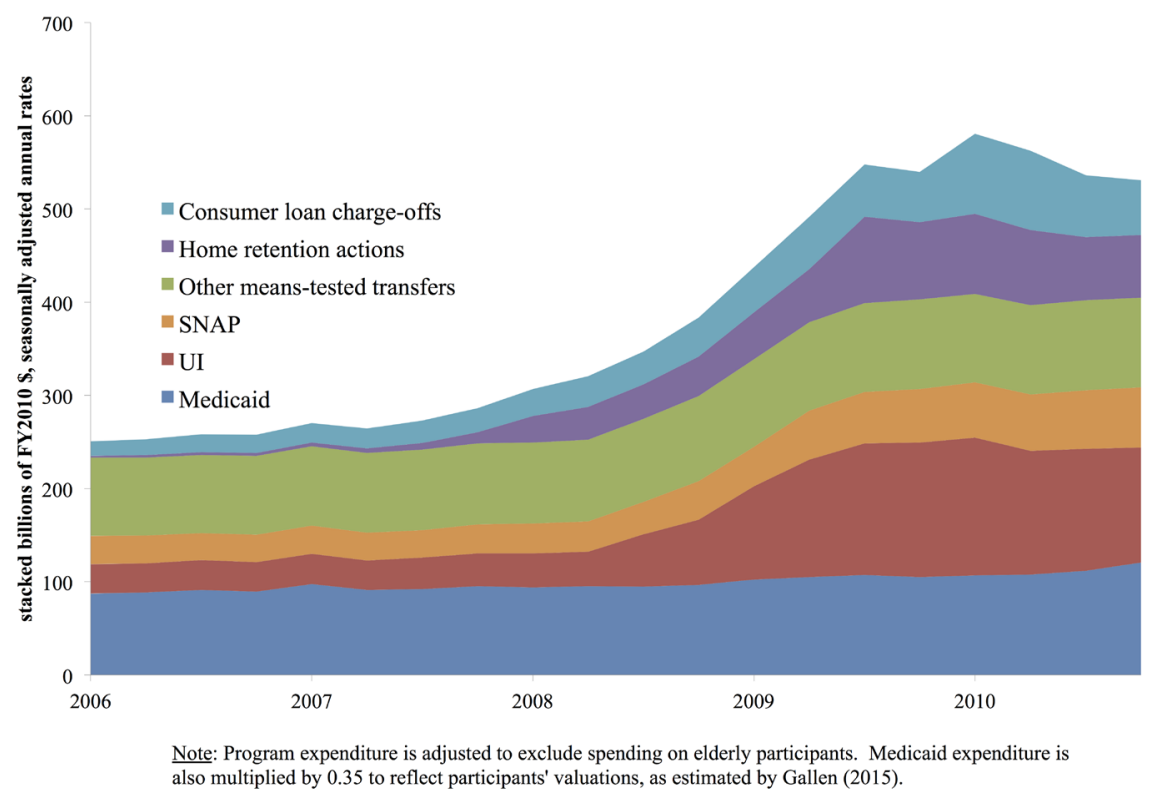

Figure 1. Transfers and loan discharges for the nonelderly unemployed and financially distressed.

${ }^{2}$ The means-tested programs included are: SSI, state and local family assistance, general assistance, and energy assistance. Social security, Medicare, education, veterans benefits, and various medical, retirement and pension transfers are excluded because some of them are either (a) not means-tested or (b) the beneficiaries are primarily elderly (below I explain more about the model's two population groups). A large majority of the increase shown in the chart is from unemployment insurance and federal spending on food stamps. Following [9], the value of Medicaid to recipients is taken to be 35 percent of their cost. The spending and loan-forgiveness data are assembled, and adjusted to exclude elderly recipients, in Figure 3.8 of [6]. 
per year. The combination (hereafter, "combined subsidies") reached almost $\$ 550$ billion per year by the second half of 2009 , or almost quadruple of unemployment benefits by themselves ${ }^{3}$. This paper shows that this large increase in the amount of means-tested subsidies could have been associated with work disincentives that were large enough to generate changes in the major macroeconomic aggregates that are in the direction and amounts resembling the actual changes.

In modeling the recession as a transition to an increasingly distorted labor market, I do not assume that production and capital markets are always efficient, but rather that changes in efficiency or competitiveness over time are limited to changes in the labor market. In the short run, consumption, investment, and labor all decline, albeit in different proportions. Labor declines in the short run, because (by construction) the sole impulse is the rising work disincentive. Consumption declines because of the permanent-income effect. Thanks to the legacy of a capital stock accumulated prior to the rising work disincentives, the marginal product of capital falls with the workforce, which creates an intertemporal substitution effect on consumption partially offsetting the permanent-income effect. Thus, consumption declines less than labor in the short run, regardless of whether the new work disincentives are temporary or permanent. For the same reason that the marginal product of capital falls, the marginal and average products of labor initially rise.

If the new work disincentives are long lasting, the labor reduction will be long lasting and investment will be low for long enough to eventually reduce the capital stock by the same proportion as labor. Once the work disincentives stabilize at a higher level, the marginal product of capital can rise again, and reduce the intertemporal substitution effect that had mitigated the consumption decline. After enough time has passed with the new work disincentives in place, labor, consumption, and capital have all been reduced in the same proportions.

The equilibrium time paths for consumption and investment are compared with the quarterly aggregate time series since the end of 2007, when the recession began. The model and data agree that investment expenditure would fall 15 - 25 percent below trend, although the data show investment dropping about two quarters sooner than predicted by the model. If labor were expected to be depressed for a long time after 2009, consumption dynamics in the model are similar to those in the data. In this sense, a large majority of this recession's consumption dynamics and investment decline were a reaction to, and anticipation of, low levels of labor usage.

Consistent with the model, the percentage consumption decline was much less than the percentage decline in work hours. Total factor productivity did not sig-

${ }^{3} \mathrm{~A}$ long literature ([10] is one of the classics) has recognized that unemployment benefits are a work disincentive, and a few papers have offered back-of-the-envelope calculations of the unemployment rate effect of extending unemployment benefits during this recession [11]. The contribution of my paper is to consider this recession's extended and expanded unemployment benefits in combination with several other means-tested subsidies in an equilibrium framework for evaluating effects on consumption, investment, wages, etc. 
nificantly deviate from prior trends. Real wages per hour and labor productivity rose in absolute terms, and relative to prior trends. A large and obvious "labor wedge" emerged during the recession ([1] [12]).

The model is also a tool for using, without the benefit of hindsight, consumption and investment data during a recession to help predict how deep and long labor will remain depressed. Through the lens of the model, actual consumption behavior through 2009 indicated that subsequent labor usage was expected to average at least five percent below the previous trend (at the time, labor was about nine percent below trend). It is more difficult to predict, on the basis of the model and aggregate behavior through 2009, whether the subsequent five percent below trend would be achieved through still further declines in the short run followed by a subsequent increase back to trend, or whether labor would always remain significantly below its previous trend.

\section{The Neoclassical Growth Model with Targeted Means-Tested Subsidies}

Consider an economy with many identical families, each with many family members. Family members will ultimately differ in terms of whether and how much labor they supply to the market, and in their expectation that they will be eligible for a means-tested subsidy in the event that they are not working. In order to simplify a complex reality in which there are many means-tested subsidy programs each with its own eligibility rules, I partition the family into just two groups: "prime" members who have a probability $p>0$ of receiving a meanstested subsidy in the event they are not working (more below about this probability), and "others" who are never eligible for means-tested subsidies. The relative size of the two groups, which I assume to be constant over time, is not relevant for my qualitative results or even many of my aggregate quantitative findings, but in cases that it does matter I measure the prime group as persons aged 25 - 64 because they are likely to have a recent history of employment covered by unemployment insurance, be heads of households with children, and/or have home mortgages and consumer credit that may be partly forgiven by lenders on the basis of "ability to pay."

Time is continuous. Gross output is produced with capital and prime labor, and is (exhaustively) used for market consumption goods and gross investment:

$$
A n_{t}^{\alpha} k_{t}^{1-\alpha}=c_{t}+\dot{k}_{t}+\delta k_{t}
$$

where $n$ denotes prime labor input, $k$ denotes capital input, and $c$ denotes market consumption, each relative to a constant exponential trend that reflects the constant exogenous growth rates for population and technology [13]. $t$ is the time subscript and $A>0$ and $\alpha \in(0,1)$ are constant technology parameters. Dots denote time derivatives, and $\delta>0$ reflects the rate of capital depreciation as well as population growth and rates of technical progress.

Prime members split their time between market production $(n)$ and household production. Non-prime members can put time $m$ toward the same household production that engages prime members (to the extent that the preference 
parameter $\beta>0$ differs from one, the two types are differentially productive in the household) and thereby shift the supply of prime members to market activities ${ }^{4}$. When date $t$ the flow of market consumption is $c_{t}$ prime members supply $n_{t}$ units of labor, and other members supply $m_{t}$ units of labor, the representative household's flow of utility $u_{t}$ is:

$$
u_{t}=\frac{\sigma}{\sigma-1} c_{t}^{(\sigma-1) / \sigma}-\gamma_{n} \frac{\eta}{\eta+1}\left(n_{t}-\beta m_{t}\right)^{(\eta+1) / \eta}-\gamma_{m} \frac{\eta}{\eta+1} m_{t}^{(\eta+1) / \eta}
$$

where the positive constants $\eta, \sigma, \gamma_{n}$, and $\gamma_{m}$ also denote preference parameters. $\sigma$ is the constant elasticity of substitution of consumption over time, and $\eta$ is the constant Frisch elasticity of labor supply. In order to rule out unrealistically large intertemporal substitution effects, I make the weak assumption that $\sigma \leq 1 /(1-\alpha)^{5}$. For simplicity, and because of my lack of emphasis on the composition of employment, Equation (2) assumes that the utility function is homothetic in the two amounts, and that the prime labor enters additively with the non-prime labor $^{6}$. Households discount the utility flows at constant rate $\rho>0$, which may also reflect exogenous growth rates of population and technology.

Firms rent the labor of prime family members at rate $w_{t}$ in the labor market (market consumption $c$ is the numeraire good). Prime members who work at date $t$ supply one unit of labor. Prime members who do not work at date $t$ receive subsidy $b_{t}$ with probability $p_{t}$ and no subsidy with probability $1-p_{\dot{b}}$ their expected replacement rate from the time $t$ subsidy is $\tau_{t}=p_{t} b_{t} / w_{t}$, which is assumed to be less than one for all $t$. Other family members work, if at all, producing household services, as indicated by the utility function (2). Assuming that households own the capital and rent it to firms at gross rental rate $r$, a household's dynamic budget constraint is:

$$
n_{t} w_{t}+\left(\Gamma-n_{t}\right) \tau_{t} w_{t}+r_{t} k_{t}=c_{t}+\dot{k}_{t}+\delta k_{t}+L_{t}
$$

where $L_{t}$ denotes date $t$ lump sum taxes, and $\Gamma$ is the prime worker time endowment.

Given values for the scalar taste and technology parameters, a value for the initial capital stock $k_{0}$, and a time path for the replacement rate, a market equilibrium is a list of time paths on $t \geq 0$ for utility flows, consumption flows, capital, both types of labor, wage rates, capital rental rates, and lump sum taxes such that: the subsidy program's budget constraint $L_{t}=\left(\Gamma-n_{t}\right) \tau_{t} w_{t}$ balances at each date $^{7}$; and-taking as given the time paths for factor rental rates, replacement rates, and lump sum taxes-the paths for utility, consumption, labor, and capital

\footnotetext{
${ }^{4}$ The work activities of the non-prime members include child care, food preparation, etc. Some of these may be counted in measured GDP in addition to the output shown in Equation (1) - this is discussed below in connection with the empirical analysis.

${ }^{5}$ For example, with $\alpha=0.7$, this upper bound on the intertemporal consumption elasticity $\sigma$ is 3.3 .

${ }^{6}$ The middle term in Equation (2) can be interpreted as foregone household production and the final term as foregone leisure for the non-prime members. As a result of the functional-form assumptions, (i) the equilibrium relative marginal household products of $n$ and $m$ is constant (and equal to $\beta$ ) and (ii) the composition of labor is constant, at values that are independent of technology and public policy parameters.

${ }^{7}$ Alternatively, the tax could be a flat-rate labor income tax without affecting the results as long as the flat-rate were constant over time. In fact, there have been few changes in the federal personal income tax since 2007.
} 
(a) maximize profits $A n_{t}^{\alpha} k_{t}^{1-\alpha}-w_{t} n_{t}-r_{t} k_{t}$ at each date and (b) maximize the present discounted value of utility $\int_{0}^{\infty} \mathrm{e}^{-\rho t} u_{t} \mathrm{~d} t$ subject to (2), the household's sequence of dynamic budget constraints (3), and to a no-Ponzi condition on their capital ownership.

Equilibrium factor rental rates equal their marginal products, so the equilibrium time paths for consumption, prime labor, and capital are the solution to a two-dimensional system of differential Equations (1) and (4), plus the algebraic Equation (5), whose boundary conditions are the initial capital stock and the usual transversality condition:

$$
\begin{gathered}
\dot{c}_{t}=\sigma\left[(1-\alpha) A\left(n_{t} / k_{t}\right)^{\alpha}-\delta-\rho\right] c_{t} \\
n_{t}^{1 / \eta}=\frac{1-\tau_{t}}{\gamma} \frac{\alpha A}{c_{t}^{1 / \sigma}}\left(k_{t} / n_{t}\right)^{1-\alpha}
\end{gathered}
$$

where the constant $\gamma>0$ is a combination of the preference parameters $\eta, \beta, \gamma_{\mathrm{n}}$ and $\gamma_{\mathrm{m}}$, Differential Equation (4) is the usual consumption Euler equation equating the intertemporal marginal rate of substitution of consumption to the net marginal product of capital.

Algebraic Equation (5) equates the marginal rate of substitution between consumption and prime labor to the marginal product of prime labor net of subsidy replacement. A replacement rate $\tau_{t}>0$ is a labor distortion in the sense that it causes the marginal product of labor to differ from the marginal rate of substitution. Because the same distortion is created by explicit labor-income taxes-such as the familiar federal taxes on payroll and personal income, I use "replacement rate" and "tax rate" interchangeably. However, none of the $\tau$ changes over time examined in this paper are from explicit taxes.

Many studies have put a wedge in condition (1) by letting the productivity parameter vary over time. Other studies have also put a wedge in the consumption Euler Equation (4), perhaps with a rate of time preference or price of investment goods that varies over time. But the thesis of this paper is that a large fraction of this recession can be understood as a consequence of a time-varying labor wedge alone, and that much of that wedge has to do with subsidies available to the unemployed and financially distressed ${ }^{8}$, so I have omitted those possible sources of time-variation.

The functional form (2) for the disutility of labor implies that consumption and leisure are normal goods and has been occasionally used in the macroeconomics literature, although for different reasons. My purposes here are simplicity and a maximum of analytic results and to have consumption, capital, and labor all change in the same proportions in the long run.

\section{Dynamics of the Stationary System}

If the labor distortion were constant over time, the dynamical system (1), (4), (5)

${ }^{8} \mathrm{~A}$ labor distortion or "labor wedge" has also been used to model labor market regulations [14], other market distortions ([3], [15]), as well as errors in the specification of the marginal rate of substitution function ([4], [16]). These alternative sources of labor distortions may also be relevant in this recession, but this paper does not attempt to quantify them except perhaps as residual labor wedge changes that cannot be attributed to subsidies. 
would be stationary and saddle-path stable, with only the saddle path satisfying the transversality condition. The stationary state of the system $\left(c_{s s}, k_{s s}, n_{s s}\right)$ has a closed form solution:

$$
\begin{gathered}
k_{s s}^{1 / \eta+1 / \sigma}=\frac{1-\tau}{\gamma} \frac{\alpha}{(\delta+\rho)^{(1 / \eta+1) / \alpha-1}(\alpha \delta+\rho)^{1 / \sigma}} A^{(1 / \eta+1) / \alpha}(1-\alpha)^{(1 / \eta+1) / \alpha-1+1 / \sigma} \\
(1-\alpha) A\left(n_{s s} / k_{s s}\right)^{\alpha}=\delta+\rho \\
c_{s s}=\frac{\alpha \delta+\rho}{1-\alpha} k_{s s}
\end{gathered}
$$

The last two equations in (6) determine the steady-state ratio of market consumption and prime work to the capital stock, and do not depend on the value for the replacement rate $\tau$. Thus, a permanent increase in the replacement rate reduces the long run capital stock, and reduces market consumption and work in the same proportion.

When the replacement rate is constant, a phase diagram for saddle path stable systems describes the dynamics of the system from any initial capital stock. The $\dot{k}=0$ schedule in the $[k, c]$ plane is implicitly defined by:

$$
\begin{gathered}
c=\left[A N(c, k ; 1-\tau)^{\alpha}-\delta\right] k \\
N(c, k ; 1-\tau)^{1-\alpha+1 / \eta} \equiv \frac{1-\tau}{\gamma} \frac{\alpha A}{c^{1 / \sigma} k^{1 / \eta}}
\end{gathered}
$$

where $N(c, k ; 1-\tau)$ is the labor-capital ratio that satisfies the labor market condition (5) for given values of consumption, capital, and the replacement rate. Along $\dot{k}=0$, market consumption equals net market output, so the schedule slopes up if and only if net market output increases with capital, taking into account the positive effect of capital on labor for a given marginal utility of consumption. The maximum of this schedule therefore occurs at a capital stock that exceeds the "golden rule" capital stock that maximizes net output for a given labor, which itself exceeds the steady state capital stock for which the marginal product of capital equals the rate of time preference $\rho$. A larger value for the replacement rate $\tau$ is associated with a $\dot{k}=0$ schedule that is lower at each value of $k$.

The $\dot{c}=0$ schedule is implicitly defined by:

$$
N(c, k ; 1-\tau)^{\alpha}=\frac{\delta+\rho}{1-\alpha} \frac{1}{A}
$$

Thus, the schedule slopes down and has elasticity equal to $-\sigma / \eta$. A larger value for the replacement rate $\tau$ is associated with a $\dot{c}=0$ schedule that is lower at each value of $k$.

Figure 2 shows $\dot{c}=0$ and $\dot{k}=0$ schedules and the implied dynamics of the system. When capital is below (above) its steady state value, there is an initial value for market consumption that is necessarily below (above) its steady state value so that the dynamics of the system asymptotically approach the steady state. Proposition 1 characterizes the stable manifold containing such paths. 
The Figure shows the stationary system's steady state, dynamics, and stable manifold.

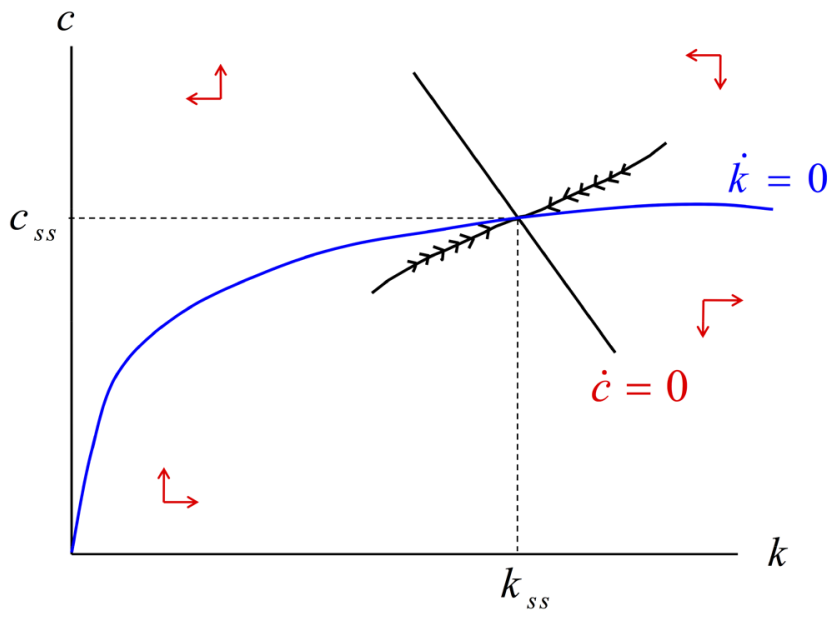

Figure 2. Capital-consumption phase diagram for the stationary system.

Proposition 1. If $\sigma \in\left(0,(1-\alpha)^{-1}\right)$, the stable manifold of the two-dimensional system of differential Equations (1) and (4), including the algebraic Equation (5), has a slope between zero and one in the [Ink, Inc] plane.

Proof. Begin with the result above that there is a unique steady state with $c_{s s}$ $k_{s s}$, and $n_{s s}$ positive. The phase diagram in the $[\ln k, \ln c]$ plane shows that $c$ increases with $k$ along the stable manifold. The phase diagram in the $[\ln k, \ln c k]$ plane shows that $c$ increases less than proportionally with $k$ along the stable manifold.

Specifically, the $\dot{c}=0$ and $\dot{k}=0$ schedules cross only once in the $[\ln k, \ln c]$ plane, thereby decomposing that plane into exactly four two-dimensional cells. The $\dot{c}=0$ schedule is linear with slope $-\sigma \mid \eta$. Consumption is growing (falling) to the left (right) of this schedule, respectively, as shown in Figure 2. The $\dot{k}=0$ schedule slopes up in the neighborhood of the steady state, as seen by differentiating (1) (again using the algebraic condition (5) to substitute out for labor) and evaluating at the steady state. Capital is growing (falling) to the right (left) of this schedule, respectively, as shown in Figure 2. Because the two schedules do not cross again, it follows that system's only time paths approaching the steady state are in the two cells for which $\dot{c}$ and $\dot{k}$ have the same sign. In other words, the stable manifold slopes up in the $[\ln k, \ln c]$ plane.

The $(c / k)=0$ and $\dot{k}=0$ schedules cross only once in the $[\ln k, \ln c k]$ plane, thereby decomposing that plane into exactly four two-dimensional cells. Both schedules slope down near the steady state, with the former sloping down less than the latter. $c k$ is growing (falling) to the right (left) of the $(c / k)=0$ schedule, respectively. Capital is growing (falling) below (above) the $\dot{k}=0$ schedule, respectively. Because the two schedules do not cross again, it follows that system's only time paths approaching the steady state are in the two cells for which $(c / k)$ and $\dot{k}$ have the opposite sign. In other words, the stable manifold slopes down in the $[\ln k, \ln c / k]$ plane. 
Table 1. Parameter values assumed for the purposes of numerical results.

\begin{tabular}{|c|c|c|c|c|}
\hline & Parameter & Value (s) & Units & Comments \\
\hline$\alpha$ & labor's share & 0.7 & share & \\
\hline$\rho$ & time preference rate, adjusted & $0.5 \%$ & per year & $\begin{array}{l}\text { chosen to produce a steady-state investment to } \\
\text { adjusted output ratio of } 0.27\end{array}$ \\
\hline$\delta$ & capital depreciation rate, adjusted & $7.25 \%$ & per year & $\begin{array}{c}5 \% \text { pure depreciation, adjusted for } 1 \% \text { population growth, } \\
0.75 \% \text { technical change, and } 0.5 \text { percent } \\
\text { expected investment price trend }\end{array}$ \\
\hline$\sigma$ & intertemporal consumption elasticity & {$[0.5,2]$} & elasticity & benchmark value of 1.35 (Mulligan, 2005) \\
\hline$\eta$ & labor substitution elasticity & {$[0.4,1.1]$} & elasticity & benchmark value of 0.75 \\
\hline$A$ & productivity level & \multicolumn{2}{|c|}{ normalized } & normalized so that the low-distortion steady \\
\hline$\gamma$ & leisure preference & \multicolumn{2}{|c|}{ normalized } & state capital and prime labor are one \\
\hline$\Gamma$ & prime-worker time endowment & 1.32 & & low-distortion steady state has $76 \%$ prime labor usage \\
\hline$\theta$ & prime-worker's share of labor income & 0.9 & share & a function of the preference parameters \\
\hline
\end{tabular}

\section{Short Run Effects of a Permanent and Immediate Increase in the Replacement Rate}

A number of analytical results can be obtained for this model. Other of the results are better displayed numerically, in which case parameter values are assumed as in shown in Table 1 (Appendix I has more on calibration).

Proposition 2. A permanent increase in the replacement rate reduces the steady state capital stock, effort, and consumption in the same proportions.

Proof. See equations (6).

Figure 3 shows the steady states and stable manifolds of the stationary system with replacement rate $\tau$ and the stationary system with higher replacement rate $\tau^{\prime}>\tau$. Because the steady states lie on the same ray from the origin, and both stable manifolds cross that ray from above, the stable manifold corresponding to the lesser replacement rate lies above that corresponding to the greater replacement rate?

Lemma. Along any path satisfying (1), (4) and (5), the sign of $\dot{n}$ everywhere has the same sign as $c_{\mathrm{ss}} / k_{\mathrm{ss}}-c(t) / k(t)$.

Proof. Differentiate the labor market condition (5) with respect to time, and then substitute for $\dot{c}$ and $\dot{k}$ using (1) and (4). Solving for $\dot{n}$, and noting that $c_{s s} / k_{s s}=(\alpha \delta+\rho) /(1-\alpha)$, yields the sign condition.

Proposition 3. If $\sigma \in\left(0,(1-\alpha)^{-1}\right)$, and beginning from a steady state, the initial effects of a permanent and immediate increase in the replacement rate are to reduce labor and consumption, but consumption declines in a lesser proportion.

Proof. As shown in Proposition 2, the replacement rate affects steady-state consumption and labor in the same proportion. Because the initial (low-re-

${ }^{9}$ They cannot cross each other. To prove this, suppose not: they cross at $(k, \mathcal{c})$ with $k>k_{s s}$ and the stable manifold corresponding to the lesser replacement rate crossing from above. The labor-capital ratio $N$ must be greater on the lesser replacement rate manifold. Because the slope of each stable manifold is the ratio of $\dot{c}$ to $\dot{k}$ (each using its corresponding value of $N$ ), this means that the stable manifold for the smaller distortion is steeper, which is a contradiction. 
The Figure shows the system's dynamics and stable manifold. The dynamics shown by the red arrows correspond to the low replacement rate that prevailed before date 0 . When the new replacement rate path is first anticipated at date 0 , consumption falls, but not as far as it will fall in the long run. The new stable manifold (shown as a black path) describes dynamics once the replacement rate has reached its higher long run value.

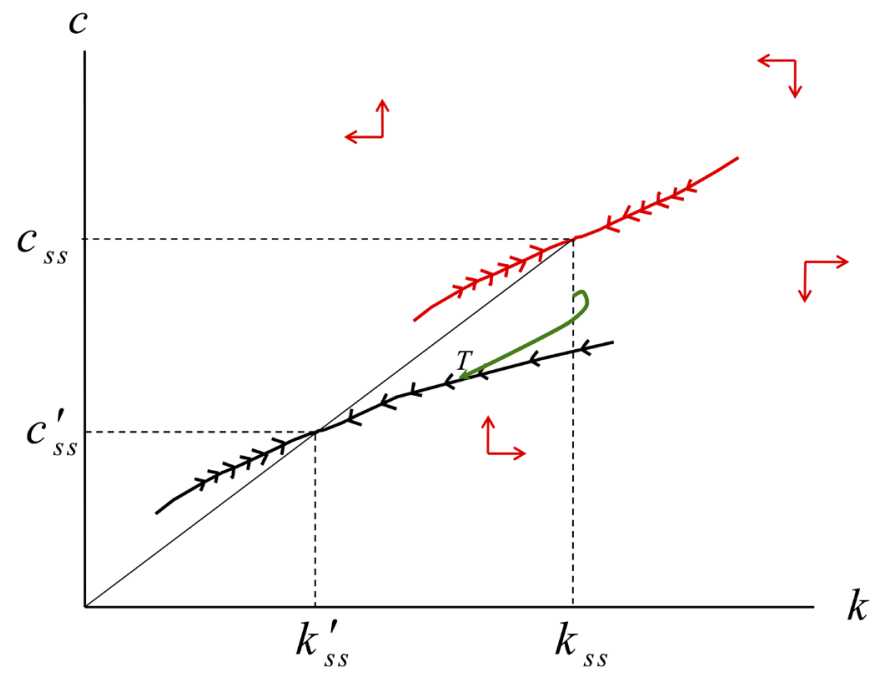

Figure 3. Stable manifolds for high and low replacement rates.

placement-rate) capital stock exceeds the new (high-replacement-rate) steadystate capital stock $k_{s s}$, Proposition 1 says that $c(t)>c_{s s}$ and $c(t) / k(t)<c_{s s} / k_{s s}$ for all $t>0$. It follows that $c(t)$ is below its previous (i.e., low-replacement-rate steady-state) value. The Lemma further guarantees that $\dot{n}>0$ and therefore that $n(t)<n_{s s^{s}}$ In other words, at time zero consumption jumps only part way to its new steady-state value $c_{s s}$ whereas labor jumps beyond its new steady-state value.

Along the transition to the steady state, capital and labor's marginal productivity schedule are temporarily high. The former has an income effect that causes labor to be temporarily low but the latter has a substitution effect in the other direction. Proposition 3's restriction on the magnitude of $\sigma$ guarantees that the former dominates.

A closed-form, albeit cumbersome, formula for the ratio of the initial change in log consumption to the initial change in log labor can be calculated in the locality of the steady state. Figure 4 displays local values for the ratio as a function of the intertemporal consumption elasticity $\sigma$ and the labor supply elasticity $\eta$, using assumed values for the parameters shown in Table $1^{10}$. The initial change in log consumption is not sensitive to the labor supply elasticity, but (due to the aforementioned conflicting income and substitution effects) does range from 31 to 54 percent of the initial impact on labor, depending on the intertemporal consumption elasticity. Thus, the result that labor's initial decline is at least twice as much as consumption's when the shock comes from a greater replacement rate holds for a wide range of parameter values, despite the fact that in the long run both labor and consumption decline by the same percentage.

${ }^{10}$ For small changes in the amount of labor market distortion, the ratio does not depend on the level of the distortion. Note that Figure 4 and Figure 9 show local results while Propositions 1-3 and Figure 6, Figure 10, Figure A1 show global results. 


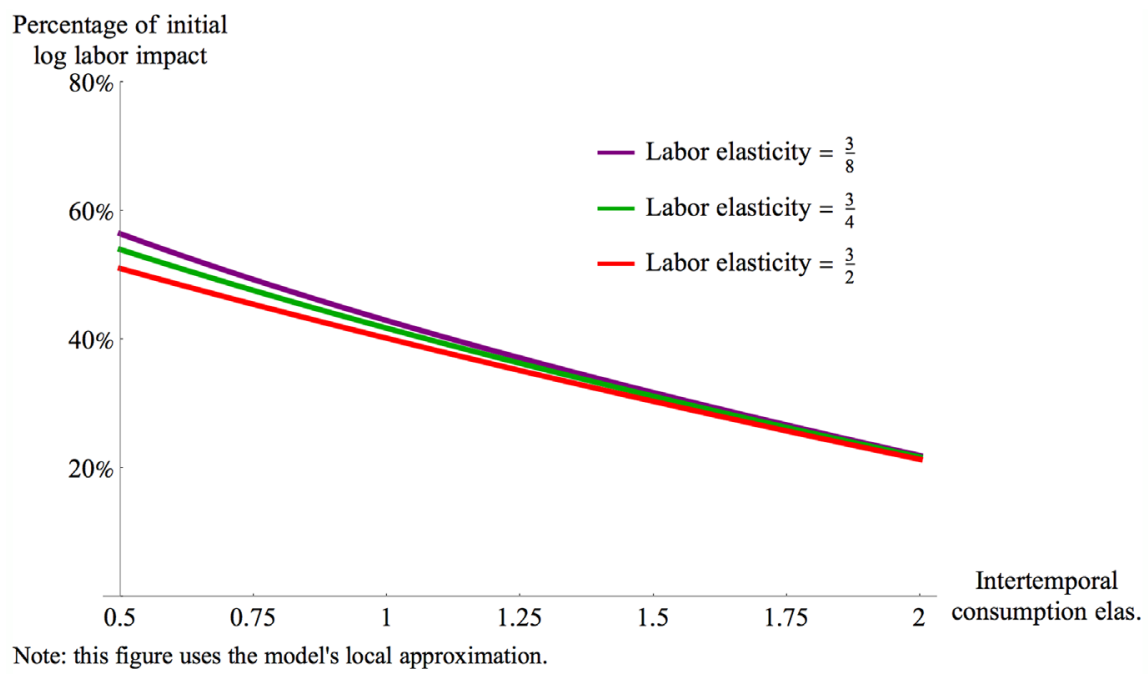

Figure 4. Initial log consumption impact of a permanent replacement rate increase.

\section{A Gradual and Permanent Increase in the Replacement Rate}

The sudden and immediate increase in the replacement rate is intellectually cumbersome because it combines two types of initial effects: the wealth effect of the news that the present value of output is less than previously thought, and the substitution effect of the initial replacement rate increase creating an increase in leisure and a reduction in consumption. More important, the actual replacement rates in the economy may accumulate continuously as, for example, the housing market continuously deteriorates, or various means-tested government subsidies are introduced or expanded at staggered dates.

For this reason, I consider a replacement rate that evolves continuously with time. At time $T$, the replacement rate reaches its long run value, which I assume exceeds its initial value. Two types of dynamics are possible, depending on whether, and how much, the peak replacement rate exceeds the long run replacement rate. I consider each case separately.

\subsection{A Gradual Monotone Transition}

Suppose that the replacement rate increases continuously and monotonically with time for $T$ years, and then remains forever after $T$ at that higher level, as shown in Figure 5. As of time $T$, the system must be on the stable manifold corresponding to the long run value for the replacement rate, which is shown in Figure 3 as a black curve. Consumption cannot jump any time after time zero, so time paths for consumption and capital prior to time $T$ satisfy the differential Equations (1) and (4), satisfy the labor market condition (5) for the replacement rate amount assumed at each date, satisfy the given initial capital stock, and terminate at time $T$ at an allocation $\{k(T), c(T)\}$ that is on the stable manifold of the stationary system with the high replacement rate. Furthermore, as shown in Figure 3's green curve, the time path in the $[k, c]$ plane approaches the stable manifold from above because the replacement rate is less before time $T$ than at 


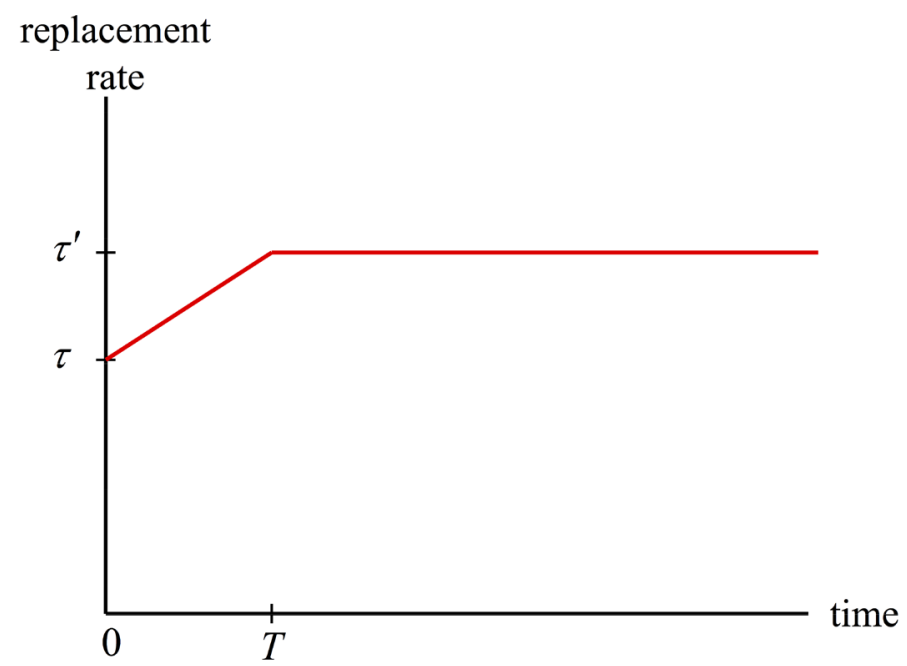

Figure 5. Time path for the gradually increasing replacement rate.

time $T$.

Not surprisingly, the initial reduction in consumption is less than it would be if the entire replacement rate change occurred immediately at time 0 , because the wealth and substitution effects on labor supply are both smaller in this case. Labor initially increases a bit, because of the adverse wealth effect and the fact that too little increase in the replacement rate is initially present to create a substitution effect. The initial labor increase raises the marginal product of capital and consumption growth (after consumption's initial jump down), which motivates some investment in the short run. As the replacement rate increases, labor, investment, and consumption growth fall. The length of the initial high-labor period depends on the size of relative wealth and substitution effects on labor supply, and how quickly the replacement rate approaches its long run value.

Between time zero and time $T$ the replacement rate has not yet hit its maximum, and an observer might wonder how much larger the replacement rate will get. The answer to this question is revealed by labor and consumption behavior: labor and consumption growth above (below) steady state values means that the replacement rate will (will not) get significantly larger. In other words, the fact that more labor is used in the face of a higher replacement rate reveals that agents are attempting to save in preparation for a still higher replacement rate.

The initial labor and investment increase turns out to be short-lived. To see this, consider numerical simulation of equilibrium time series using the benchmark parameter values shown in Table 1 and a replacement rate that linearly transitions from 25 percent to 37 percent over two years (the end of 2007, correspond to the model's time $t=0$, through the end of 2009) and then remains at that level forever ${ }^{11}$. The model's aggregate quantities are displayed as red curves in Figures 6(b)-(f) (the other series shown in the Figures are explained below). The vertical axis normalizes each series relative to the low-replacement-rate-

\footnotetext{
${ }^{11}$ Appendix I explains the numerical nonlinear simulation method, as well as the sensitivity of results
} to assumed parameter values. 


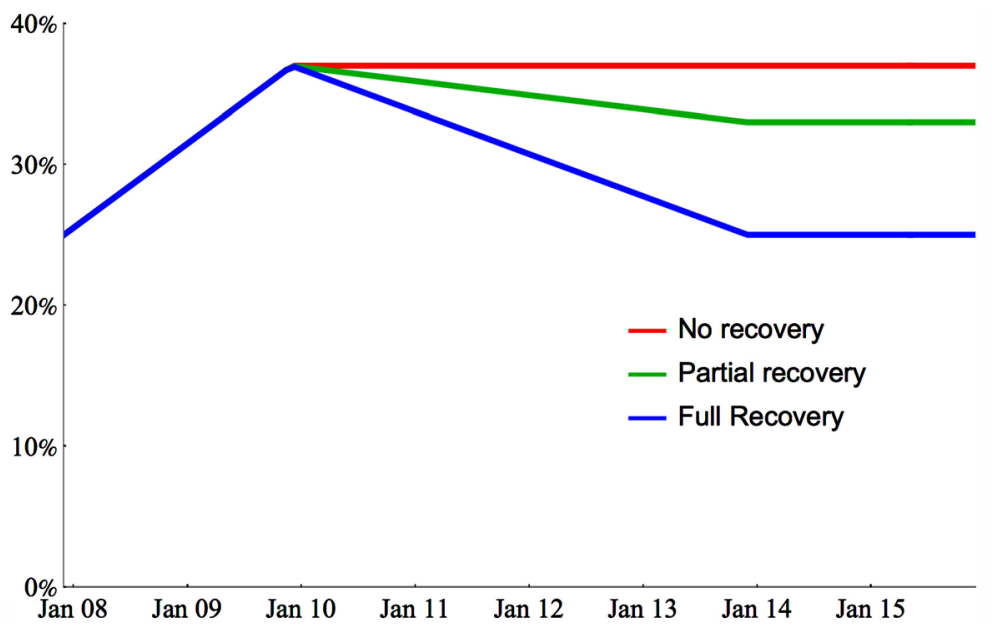

(a)

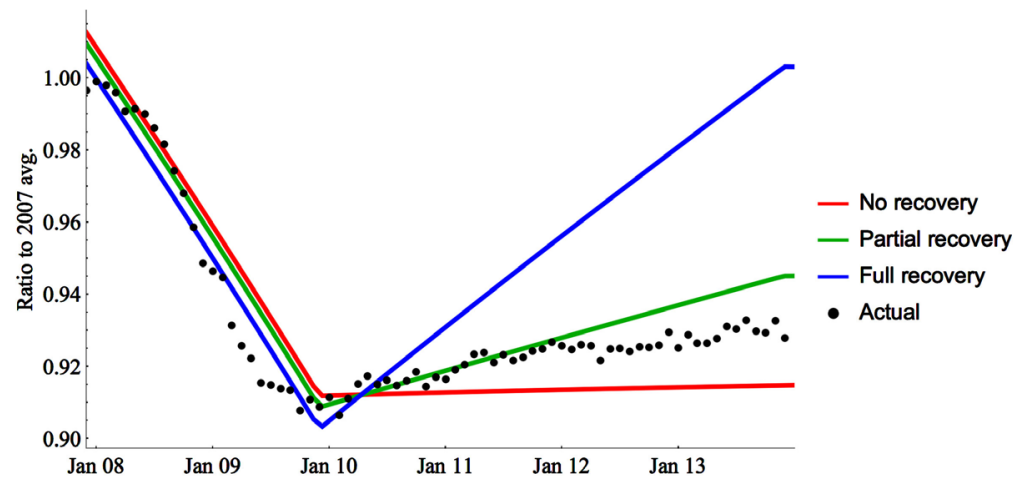

(b)

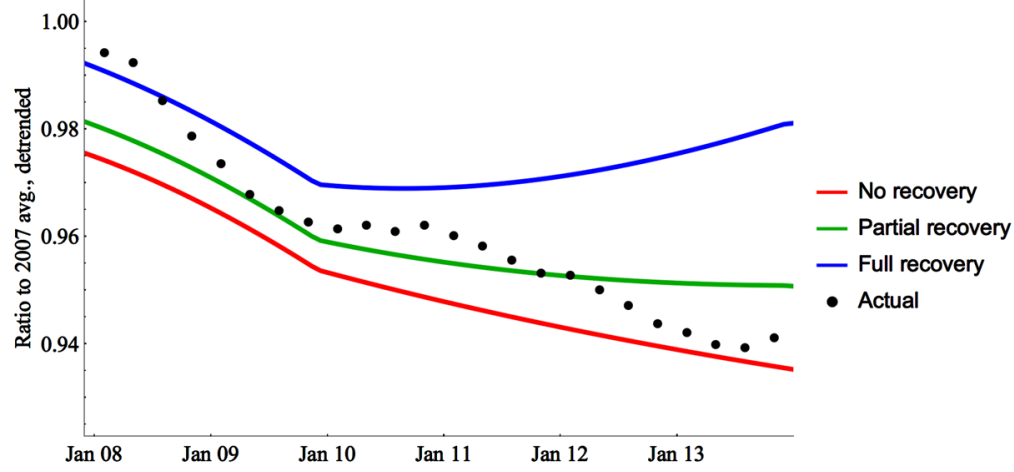

(c)

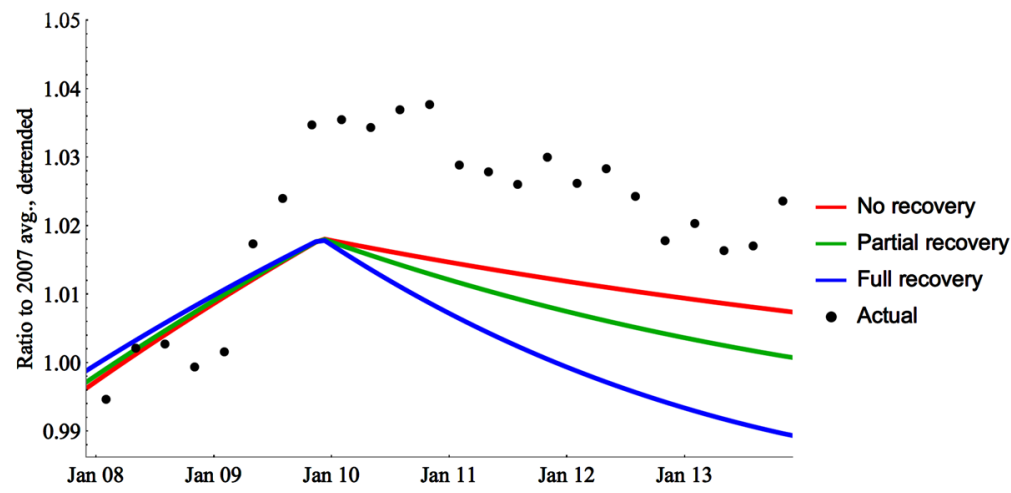

(d) 


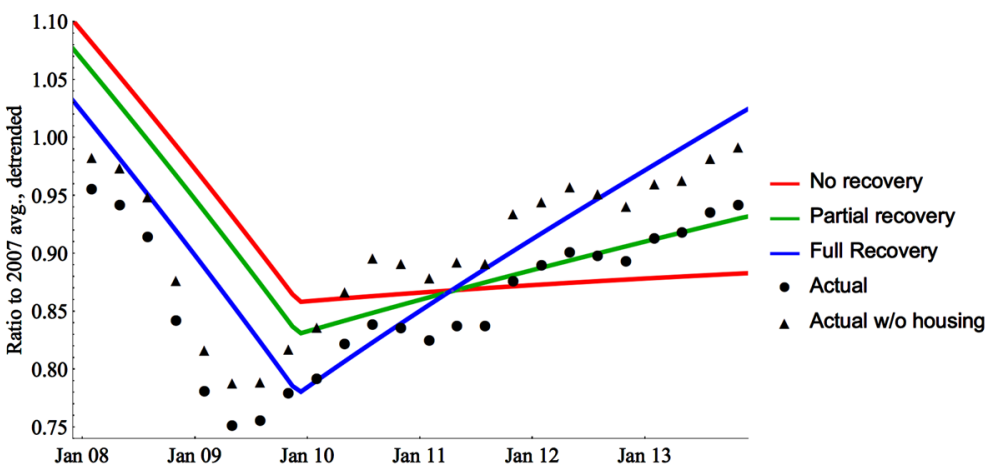

(e)

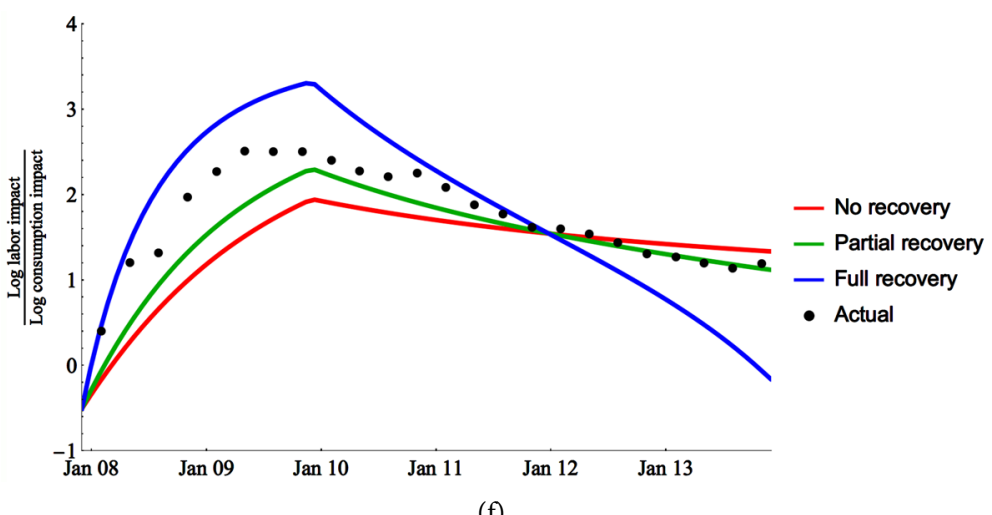

Figure 6. (a) Earnings replacement rates: 3 scenarios for beyond 2009; (b) Labor usage: actual compared with 3 scenarios; (c) Consumption: actual compared with 3 scenarios; (d) Labor productivity: actual compared with 3 scenarios; (e) Investment: actual compared with 3 scenarios; (f) Relative impact: actual compared with 3 scenarios.

steady-state values, which are assumed to be the values that prevailed before time zero, when it, according to the model, became known the economy would be additionally distorted in the future (with dynamics shown in Figure 3). Because the aggregate production function is assumed to be Cobb-Douglas (marginal and average products are in fixed proportions), and the time series are shown relative to their low-replacement-rate-steady states, the same series that graphs the marginal product in Figure 6(e) would also graph the average product.

As noted above, simulated labor is initially high, but Figure 6(b) shows that it is only about one percent above the low-replacement-rate-steady-state, and even then falls below the low-replacement-rate-steady-state within about two months. By the end of the second year, simulated labor has fallen about nine percent and consumption (Figure 6(c)) has fallen less than five percent. The marginal and average products of labor have risen three percent (Figure 6(d)).

\subsection{A Gradual Non-Monotone Transition}

At least part of the subsidies shown in Figure 1, such as unemployment insurance that was available for up to 99 weeks, were expected to be, and ultimately were, temporary. Others, such as underwater mortgages in certain parts of the 
country, could linger for a longer time. Moreover, new taxes to pay for (and, sometimes, means-tests associated with the distribution of) growing public pensions and publicly financed health care, were expected to, and ultimately did, replace some of the temporary marginal tax rate effects of the programs shown in Figure 1. For these reasons, I also consider a gradual increase in the replacement rate that reverses itself before settling at a constant value that is at least as large as the pre-existing replacement rate.

Two kinds of dynamics are possible depending on how much the peak replacement rate exceeds its long run value. If the peak is not too much above the long run value (i.e., the replacement rate's time path is sufficiently close to monotonic), then the dynamics are like Figure 3's green curve except that the path in the $[k, c]$ plane approaches the stable manifold of the stationary system with the long run replacement rate from below. As for the path shown in Figure 3, this path has consumption and capital falling as time $T$ approaches, and there is never a time during which capital is rising from a value below its initial one.

If the replacement rate's peak is high enough relative to its long run value, capital will drop below its long run value for some time sub-interval of $[0, T]$. In this case, consumption and capital reach their lows before time $T$ and are rising thereafter ${ }^{12}$. Figure 7 shows a time path for this case in the $[k, c]$ plane.

The contrast between these two possibilities shows how aggregate time series for the first part of the recession can help an observer determine whether replacement rates were expected to get significantly smaller. In both cases, the economy reaches a point at which labor rises and the replacement rate falls. But capital rises and net investment is positive only (that is, gross investment exceeds the amount needed to keep up with population growth, depreciation, and technological progress) if labor is anticipated to get significantly higher.

The Figure shows the system's dynamics and stable manifold. The dynamics shown by the red arrows correspond to the low replacement rate that prevailed before date 0 . When the new replacement rate path is first anticipated at date 0 , consumption falls, but not as far as it will fall in the long run. The new stable manifold (shown as a black path) describes dynamics once the replacement rate has reached its higher long run value.

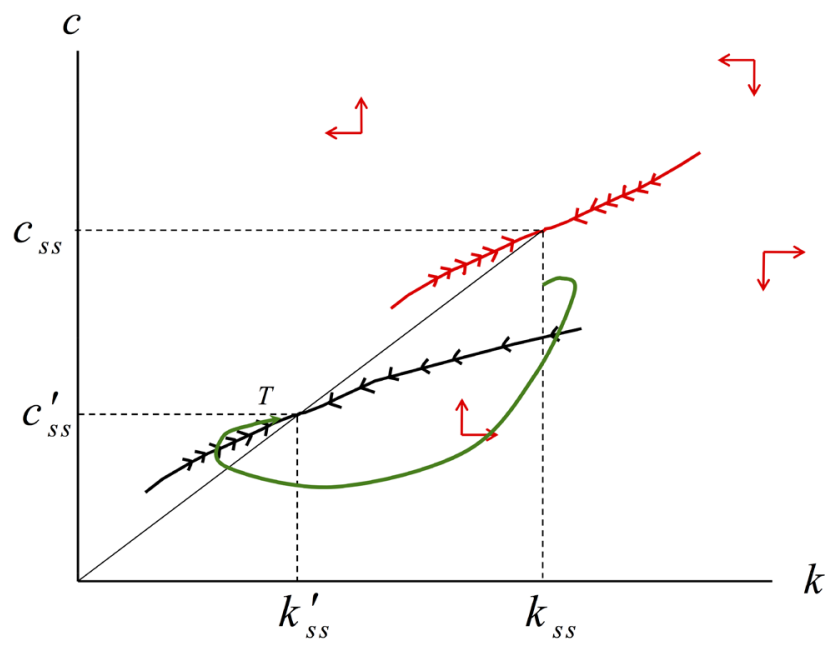

Figure 7. Dynamics when the replacement rate increase is largely temporary.

${ }^{12}$ The path in the $[k, c]$ plane approaches the stable manifold of the stationary system with long run replacement rate from above, and thereby crosses that stable manifold at least twice. 


\subsection{The Amount of Distortion Coming from Means-Tested Subsidies}

The combined subsidies shown in Figure 1 potentially replace a lot of what prime-aged workers would have earned if they all had been working. Figure 8's "measured series" displays my calculation of an expected replacement rate $\tau_{t}=$ $p_{t} b_{t} / w_{t}$ by dividing the combined subsidies by an estimate of the aggregate foregone full-time earnings of all non-working prime aged persons, which is itself the product of their numbers and a $\$ 3885$ per month estimate of the median employer cost of prime-aged persons who did work full-time ${ }^{13}$. This measured replacement rate increases about 11 percent points from before the recession to late 2009. These changes are added to a baseline labor-income tax rate of $\tau=25$ percent that also reflects longstanding income and payroll tax rules that were not significantly changing during this period ${ }^{14}$.

Conceptually the average replacement rate is just the ratio of what the average non-employed person gains in terms of subsidies as a consequence of not working, expressed as a ratio to what he would have earned if he had been lucky (or willing) enough to have a full-time job. There are two basic approaches to measuring the average work disincentive: statute-based and expenditure-based. The former examines tax and subsidy rules (a.k.a., statutes) individual-by-individual and margin-by-margin and calculates an overall average. Reference [17] took this approach to measuring work disincentives from federal payroll and income taxes, which [6], [18], and [19] extended to several other federal programs during the recent recession.

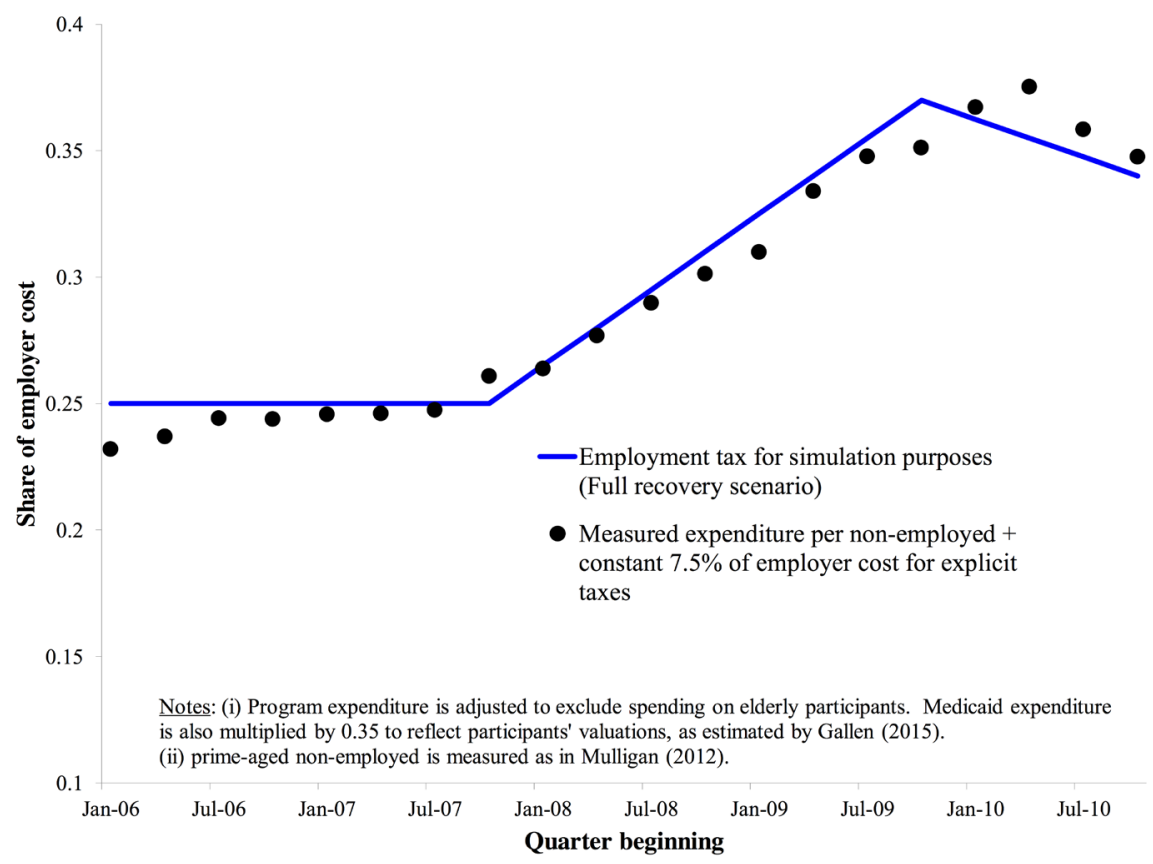

Figure 8. Average marginal tax on employment for prime-aged persons.

\footnotetext{
${ }^{13} \$ 3885$ is the value calculated by Chapter 3, note 54 of [6].

${ }^{14}$ There was a partial federal payroll tax holiday in 2011 and 2012 (see [6]).
} 
The statutory approach can seem opaque because statutes can be opaque, and the law is not always enforced. It also makes it difficult to compare results across jurisdictions that have different statutes and enforcement regimes [20]. Figure 8, and the rest of this paper, therefore takes the expenditure-based approach by dividing expenditure on subsidies for people out of work by the number of people out of work. In the model, and in reality, the causality between employment and total expenditures on means-tested subsidies (Figure 8's numerator) goes in both directions ${ }^{15}$. Note that an increase in the number of people out of work by itself reduces the disincentive as measured by Figure 8, which means that disincentives measured this way cannot increase during a recession unless subsidy spending increases proportionally more than the number of people out of work $^{16}$.

Many of the subsidies featured in Figure 1 are temporary but nonetheless may last a number of years, and may be replaced in the future by distortions from income tax hikes or a more permanent expansion of the welfare state ${ }^{17}$. Therefore, I consider three replacement rate scenarios: (a) a permanent replacement rate increase, (b) a fully temporary replacement rate increase (the "full recovery" scenario), and a partially temporary replacement rate increase (the "partial recovery" scenario). All three scenarios have the same replacement rate series through the end of 2009, and differ in terms of what happens thereafter. The partial recovery scenario mimics the "theoretical" series intended to closely approximate the replacement rate measures in Figure 8, continuing the same downward trend from the beginning of 2011 to the end of 2013, at which time it remains constant at 33\% (two thirds of the way between the permanent scenario's long run value of $37 \%$ and the full recovery scenario's long run value of $25 \%$ ). For each replacement rate scenario, the paper then examines the equilibrium response of the rest of the economy, and compares that response to actual experience.

\section{Monthly and Quarterly Indicators of Aggregate Economic Quantities}

The model is especially simple in that output has only two uses: as consumption or investment. The national accounts offer more detail than this, so I aggregate nondefense government consumption, private nondurable consumption, and private service consumption into a single consumption aggregate ${ }^{18}$. Gross do-

${ }^{15}$ The model's subsidy expenditure is $\left(\Gamma-n_{t}\right) p_{t} b_{t}$ a reduction in prime labor for any reason would, holding constant the expected benefit $p_{t} b_{t}$ cause more spending on means-tested subsidies.

${ }^{16}$ It is possible that the people who left employment during this period were entitled to more assistance than the average household head or spouse who was already out of work, thereby increasing program spending by a greater proportion than the number out of work. This and other concerns are why both the statute-and revenue-based approaches coexist in the literature. However, when it comes to the recent recession, the distinction is perhaps academic because the two approaches reveal similar estimates because the combined statutory changes were so large (Chapter 3 of [6]).

${ }^{17}$ In this sense, my simulation results can be interpreted as an American transition from its 2007 welfare state, to a welfare state more like Europe's, as modeled by [21].

${ }^{18}$ The quarter-to-quarter log change in the real consumption index is the average of monthly log changes in each of the three components, weighted by their expenditure shares. A quarterly real non-defense public consumption index is calculated from the quantity indices for total government consumption and federal defense consumption. The macroeconomic aggregates used in this paper are shown in Appendix II. 
mestic private investment, government non-defense investment, and private purchases of consumer durables are aggregated together into a single investment quantity index. I also consider a second measure of investment that excludes residential investment, because housing capital is likely less complementary with labor than business capital is. Labor input is measured as aggregate weekly hours of paid employment divided by the number of adults in the population. The average product of labor is measured as the ratio of real GDP to labor input.

Model households provide their own household services, but in practice many household services like childcare, or close substitutes for them like dining services, are traded in the marketplace. The model's best analogue for date $t$ national accounts expenditure on nondurable consumption goods and services is therefore $c_{t}+\beta\left(1-\tau_{t}\right) w_{t} m_{t}$. Similarly, the model's best analogue for date $t$ national accounts GDP is $A n_{t}^{\alpha} k_{t}^{1-\alpha}+\beta\left(1-\tau_{t}\right) w_{t} m_{t}$.

The model is expressed relative to constant exponential trends for population and labor productivity ${ }^{19}$. Quantity variables are therefore measured on a per capita basis and then (except for labor) detrended by $0.75 \%$ per year for expected labor-augmenting technical change. To be consistent, the model's depreciation rate is taken as a pure depreciation rate plus expected population growth of one percent per year and the same trend for expected productivity growth ${ }^{20}$. Expected productivity growth is particularly speculative, so sensitivity analysis is shown.

Figures 6(b)-(e) compare the three scenarios from the model to the measured time series for labor usage, real consumption, the average product of labor, and real investment. The Figures express model variables as a ratio to their values in the steady state with the small replacement rate $\tau$, and measured variables as a ratio to their average value in 2007. The model paths are labeled "full recovery," "no recovery," and "partial recovery" to reflect the assumed replacement rate time paths (see Figure 6(a)).

Figure 6(b) compares the model with measured labor data. The fact that all three model labor paths decline through year two is largely a result of Figure 8's finding that average replacement rates rose during that period. However, the fact that all three model labor paths ultimately decline about nine percent over those two years is a combination of Figure 8's finding that replacement rates rose about 12 percentage points, the benchmark assumption that the Frisch wage elasticity of labor supply is 0.75 , and the benchmark assumption that labor's share is $0.7^{21}$.

\footnotetext{
${ }^{19}$ For example, $\delta$ in the model is not only capital's rate of economic depreciation, but also the rate at which capital must be augmented to keep up with population and exogenous technical change (for more on growth models with exogenous trends, see [13]).

${ }^{20}$ The rate of time preference also reflects population and productivity growth, but its value is calibrated to match data on the consumption-output ratio (see Table 1).

${ }^{21} \mathrm{~A}$ partial equilibrium back-of-the-envelope calculation illustrates the magnitudes: the change in log labor is the change in the log of the after tax share (i.e., $\log (1-0.37)-\log (1-0.25))$ times the incidence parameter, which is the product of the magnitudes of the labor demand elasticity $(1 /(1-0.7)$ $=3.33$ ) and the labor supply elasticity (0.75) divided by their sum. The result of the partial equilibrium calculation is -0.11 , as compared to -0.09 for the general equilibrium calculation, which includes a wealth effect.
} 
For the moment, consider only the scenario represented by the red series in each Figures 6(a)-(f), which assumes that the replacement rate follows the pattern shown in Figure 5 with $\tau=25 \%, \tau^{\prime}=37 \%$, and $T=2$. In words, the replacement rate stops rising in early 2010, but never falls. As in the model, measured real consumption drops the most early in the recession and continues to drop gradually thereafter, although measured consumption does not literally make the instantaneous jump that it does in the model. Whether measured to include residential investment (circles in Figure 6(e)) or not (triangles in Figure 6(e)), actual investment is somewhat lower than model investment, although both model and actual fall sharply and hit bottom between 75 and 85 percent of their pre-recession values through about two years. As in the model, measured labor productivity rises during the recession, and is about one percent above pre-recession values through about two years.

Even though Figure 8's expected replacement rates increased dramatically, that doesn't prove that the increase is responsible for the labor usage decline, because in principle labor usage could be fairly insensitive to replacement rates ${ }^{22}$. That possibility is embodied in my model's Frisch labor supply elasticity $\eta$, which was assumed to be 0.75 for the purposes of Figures $6(\mathrm{~b})-(\mathrm{e})$.

Given the noticeable quantitative resemblance between the data and such a simple model, it is worth considering what the model suggests about the causes of the recession, and where the economy was headed after the recession ended. The next section calculates the consumption implications of alternative scenarios for the future of the replacement rate, finding that a "partial recovery" scenario fits the consumption data best. It concludes by offering some interpretations of the investment decline that occurred during this recession.

\section{Indicators of the Labor Market's Future, and the Magnitude of Investment Distortions, from Current Consumption and Investment Behavior}

The model says that consumption falls the most early in the recession, and that the magnitude of the drop depends on the time path for the replacement rate. In other words, consumption is a leading indicator of labor, and could be used with early-recession data to forecast the labor market thereafter.

Consider first the immediate and permanent replacement rate increase considered above. Figure 4 showed comparative statics of the ratio of the initial log consumption impact to the initial log labor impact, which was essentially the

\footnotetext{
${ }^{22}$ It is interesting, but beyond the scope of this paper, to explain why replacement rates increased since 2007, rather than some other time period. Part of the explanation may be the high debt burden accumulated by households prior to 2007. Perhaps national electoral victories by the Democratic party set the political stage for the expansion of means-tested programs, or reflected increased support for such programs among voters. The endogenous erosion of "welfare stigma" (or the diffusion of welfare information) along the lines of [22] and [23] could be another story: as more people lose jobs and collect benefits, others feel less stigmatized by collecting them (or become aware that such benefits are available), which raises program expenditures for a given size of the eligible population, while that endogenous increased likelihood of program participation reduces the perceived cost of being unemployed and thereby expands the size of the eligible population to the extent that labor supply is elastic. See also [24].
} 
same as the long run log labor impact. For example, if that ratio were $34 \%$ (as it is for $\eta=0.75$ and $\sigma=1.35$ ), then the long run log labor impact would be about triple the initial log consumption impact.

\subsection{Consumption as a Leading Indicator of Labor}

Figure 6(c) shows the measured consumption data, and the three corresponding model paths for consumption. "Full Recovery" implies relatively little consumption decline (about three percent) through two years because the present value of the labor decline is relatively low. The other two paths show a more significant consumption decline. By the second year of the recession, both scenarios have real consumption's cumulative decline of four or five percent, and have real consumption continuing to fall beyond year two.

Another way to look at Figure 6(c) is that consumption during the recession is a leading indicator of labor as long as the replacement rate would continue evolving before reaching its steady-state value. Figure 9 pursues this idea quantitatively. For a given intertemporal consumption elasticity $\sigma$ and an observed consumption impact ${ }^{23}$, I calculate the immediate and permanent change in the replacement rate, and therefore an immediate and largely permanent change in labor, that would be needed to generate the initial consumption impact ${ }^{24}$. This calculation is repeated for many values of $\sigma$ and for the initial consumption impact. In the immediate-permanent-tax-change model, and in versions of the model where tax changes are prolonged over time, the initial consumption impact reflects the effect of tax changes on the present value of labor earnings and therefore approximately the effect of the tax on the present value of labor. Figure 9 therefore describes the calculated labor impact as the "average" impact (in the present-value sense) of news about the path for taxes, even in cases when the news involves changes that are prolonged over time rather than being immediate and permanent.

In other words, Figure 9 is a tool for using consumption data during a recession to help predict how deep and long labor will remain depressed. Take the 2.1 percent that consumption dropped below trend during the first year of the recession (2007-Q4 through 2008-Q4). With an intertemporal consumption elasticity of 1.35, Figure 9 says, without relying on any data beyond 2008-Q4, that the average labor impact of the recession was -6.2 percent. Now that several years have passed since 2008-Q4, we can now use the "Actual" series in Figure 6(b) to see that the prediction from Figure 9 is fairly close.

By construction, a recession in my model is caused by an increase in the labor tax rate, and not by any change in preferences for consumption. Nevertheless,

\footnotetext{
${ }^{23}$ In the model, consumption jumps immediately because all tax-rate news arrives at one time, but in practice I take it to be the consumption decline through the first year of a recession. Also note that, for the purposes of Figure 9, consumption does not include any of the services of non-prime workers that are provided in the marketplace.

${ }^{24}$ For this purpose, the model is linearly approximated in the neighborhood of the steady state, and the other parameters $(\alpha, \delta, \rho)$ are assumed to take on their benchmark values. Recall from Figure 4 that this calculation is pretty insensitive to the assumed value of the labor elasticity $\eta$ ).
} 


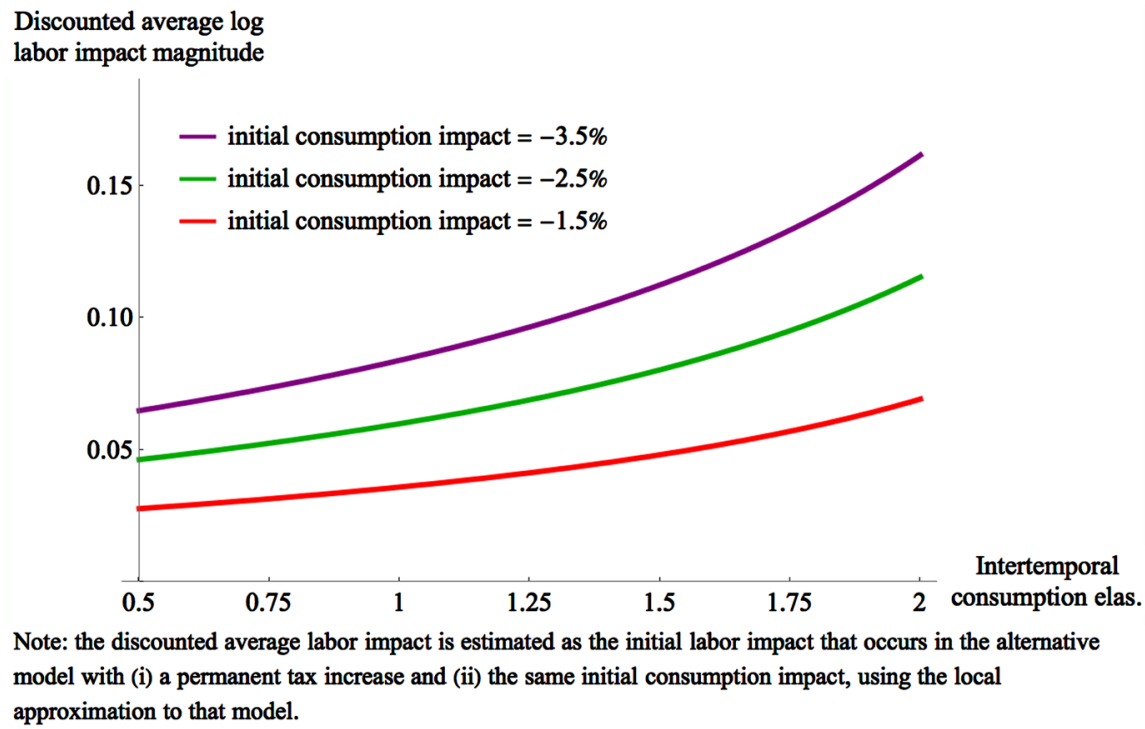

Figure 9. Inferring average labor impact from the initial consumption impact.

for the reasons mentioned above, consumption can be a leading indicator of labor. In other words, the leading behavior of consumption does not mean that consumption preferences are the primary cause of what happens to labor.

Figure 6(d) compares the labor productivity data to the three scenarios from the model. All three scenarios assume the same long-run labor productivity and have very similar predictions for labor during the first two years of the recession. Given that all three obtain most of their short run labor productivity variation from changes in the amount of labor, it is no surprise that both have similar time paths for labor productivity during the first two years. All three scenarios over-predict actual labor productivity in quarters four and five by about half a percent.

Labor productivity after year two varies across scenarios largely because labor varies across scenarios. Nevertheless, all three scenarios under-predict productivity after year two by at least one percent and sometimes more than two percent.

\subsection{Much, but Not All, of the Investment Decline Appears Efficient Given the Rising Replacement Rate}

As shown in Figure 6(e), all three scenarios predict that real investment would drop sharply, to 78 - 85 percent of the pre-recession value by the end of the recession's second year. Through the middle of the second year, the data also show real investment about 75 percent of the prerecession value. Investment declines in the model because capital and labor are complements in production (in the sense that the marginal product of capital increases with the amount of labor), and the labor market becomes increasingly distorted with time.

The scenarios differ from each other, and from the data, in terms of investment during the first year and a half. The "full recovery" scenario fits the investment data the best of the three, and the discussion of labor productivity re- 
sults (Figure 6(d)) suggests that this scenario's success with predicting investment may be due to offsetting errors: over-predicting consumption and (in some of the quarters) over-predicting output.

The two scenarios with heavy present value labor losses-"No recovery" and "Partial recovery"-have a short period of somewhat higher investment followed by low investment during the second year. The early investment period reflects model consumers' desire to smooth consumption, in anticipation of low output and labor usage in the near future ${ }^{25}$. The models' investment is quite low early in the second year of the recession, although measured real investment is somewhat lower (regardless of whether the measure includes housing).

The data for the middle of 2009 show investment expenditure at $75 \%$ of its 2007 value (79\% for non-housing investment), whereas the "partial recovery" model shows it at $88 \%{ }^{26}$. In this sense, low labor usage explains at least half of the investment decline.

\subsection{An Investment Distortion by Itself Does Not Fit Actual Behavior}

An alternative view of the recession is that labor usage fell, and safety net expenditures increased, as a consequence of an investment spending collapse stemming from the financial crisis, rather than being caused by an expansion of the safety net or by some other labor market distortion. My model has no investment friction, but its components indicate how the economy might evolve if the supply of funds for new investment had been curtailed. Suppose for example that gross investment were frozen at zero on the time interval [0,T]. As of time $T$ the economy would be on the stable manifold of the stationary system shown in Figure 2, with a capital stock less than its steady state value. Prior to that date, labor would be low. Close to time zero, labor would be low due to an income effect: potential output remains high and none of it is spent on investment. Closer to time $T$, capital has fallen due to lack of investment, consumption would have fallen with capital, and labor would be low due to low labor productivity. In summary, the time paths for labor usage and productivity would, for a time, be similar to what they are with the sudden and permanent labor distortion studied in Section III above, but the time path for consumption would be very different.

Moreover, unlike this example, actual gross investment has not been anywhere close to zero, and my framework offers a straight-forward calculation of the effects of investment distortions (a wedge in the consumption Euler Equation (4) that had no direct effect on the labor market condition (5) or the resource constraint (1)) that were in exactly the right amounts to replicate actual

\footnotetext{
${ }^{25}$ The early investment period would be shorter if the intertemporal substitution elasticity $\sigma$ were smaller.

${ }^{26}$ As shown in Figure 6(e), the empirical results are fairly insensitive to the inclusion of housing investment because housing investment is less than one-fifth of total investment. For the same reason, modifying the model to have separate flows of housing and business investment would have little effect on the results. The housing stock, on the other hand, is a large share of the total stock, which is why housing debt can be associated with transfer flows as large as shown in Figure 1.
} 
investment. Given an initial capital stock, a path for investment expenditure, and the taste and technology parameters, an investment-distortion equilibrium is a list of time paths on $t \geq 0$ for utility flows, consumption flows, both types of labor, wage rates, and rental rates, such that the paths for utility, consumption, and labor (a) maximize profits $A n_{t}^{\alpha} k_{t}^{1-\alpha}-w_{t} n_{t}-r_{t} k_{t}$ at each date and (b) maximize the present discounted value of utility $\int_{0}^{\infty} \mathrm{e}^{-\rho t} u_{t} \mathrm{~d} t$ subject to (2) and the household's sequence of dynamic budget constraints $(3)^{27}$.

Figure 10(a)'s red curve is the time path for labor usage from December 2007 to the end of 2013 that is an investment distortion equilibrium given that model's investment path over that time is exactly equal to the actual investment path, and given the benchmark parameters. The black circles indicate actual labor usage (the same data shown in Figure 6(b)). For the benchmark wage elasticity of labor supply, the model's labor usage declines in 2008 and 2009, with a minor recovery thereafter, but to a much lesser degree than actual labor usage. In the short run, an investment distortion has essentially no effect on the capital stock and thereby reduces labor solely because of an income effect. As the investment distortion persists, the capital stock is reduced: the income effect is smaller, and eventually in the other direction (increasing labor), while low wages tend to reduce labor. The green series shows that model predictions are similar if the elasticities $\eta$ and $\sigma$ are set to two times their benchmark values.

Figure 10(b) shows how the investment distortion model predicts reduced labor for the "wrong" reason-increased consumption. Contrary to the investment distortion model, consumption actually fell during the recession.

Figure 10(c) shows how the investment distortion model predicts rising expenditure $\left(\Gamma-n_{t}\right) \tau_{t} W_{t}$ on means-tested subsidies, but not nearly to the degree that actually occurred. Much of the investment-distortion model's subsidy under-prediction comes directly from its assumption that replacement rate $\tau_{t}$ was constant, whereas Figure 8 suggests that the replacement rate increased dramatically. The rest of the subsidy under-prediction comes from its under-prediction of the labor decline, which, depending on the assumed labor supply elasticity, in part also derives from the constant replacement rate assumption.

A credit crisis might also directly reduce consumption spending, but in this case it is unclear why the labor usage reduction would be of such a great magnitude relative to the consumption-spending drop. Figure 6(f) displays the ratio of the labor usage decline (as explained above, from a trend line determined by expected population growth) to the real consumption decline (from a trend line determined by expected population and productivity growth) in both the models and the data. Throughout the recession, the actual fall in labor usage exceeded the fall in real consumption, and by a wide margin over the last two years. The data and two of the replacement rate scenarios agree on this general pattern.

\footnotetext{
${ }^{27}$ The equilibrium quantities for any period $t \geq 0$ are calculated as the solution $\left\{c_{b} n_{t}\right\}$ to the two algebraic Equations (5) and $c_{t}=A n_{t}^{\alpha} k_{t}^{1-\alpha}-I_{t}$, where $I_{t}$ is gross investment expenditure for quarter $t$ and $\tau_{t}$ is set to 25 percent. The level of capital $k$ is normalized and its quarter-to-quarter changes are found by accumulating quarterly investment using the assumed depreciation rate.
} 


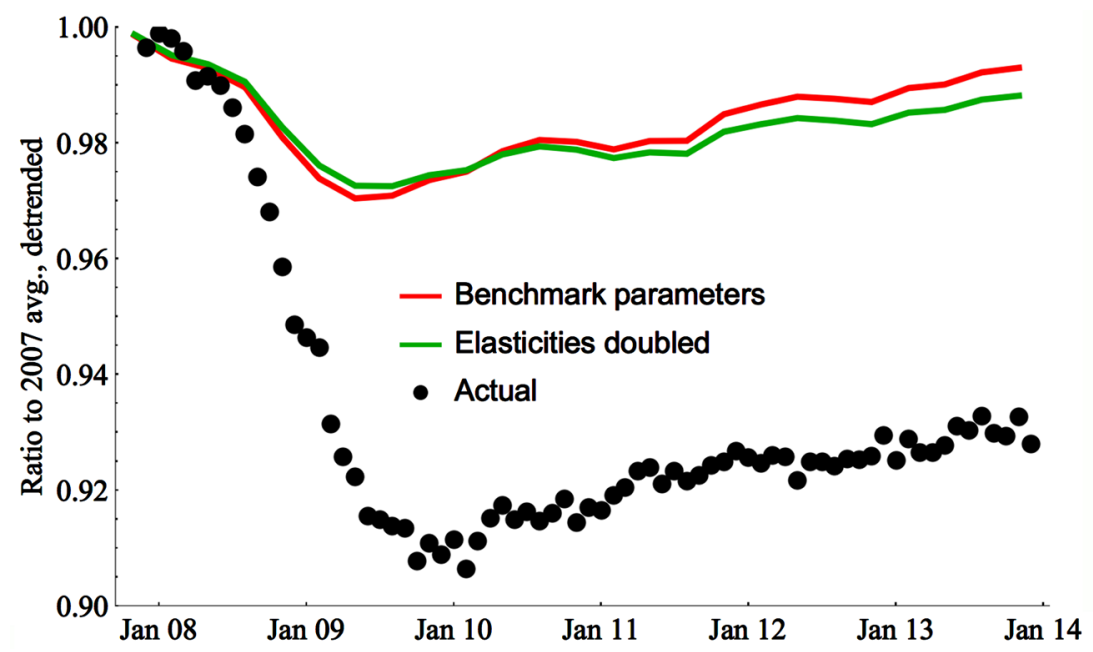

(a)

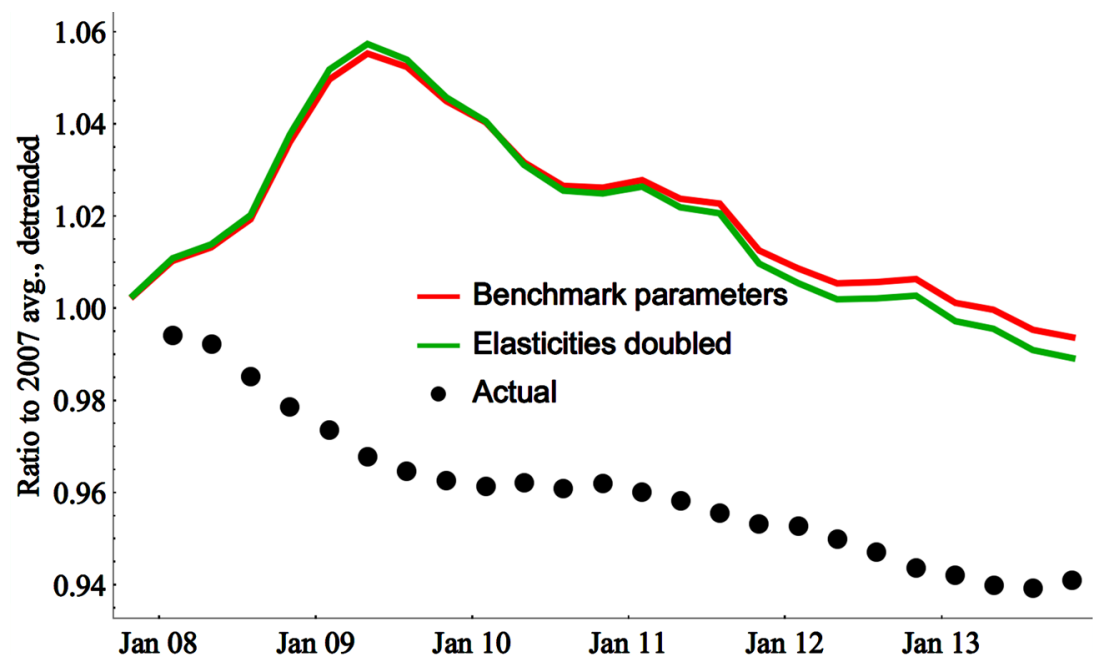

(b)

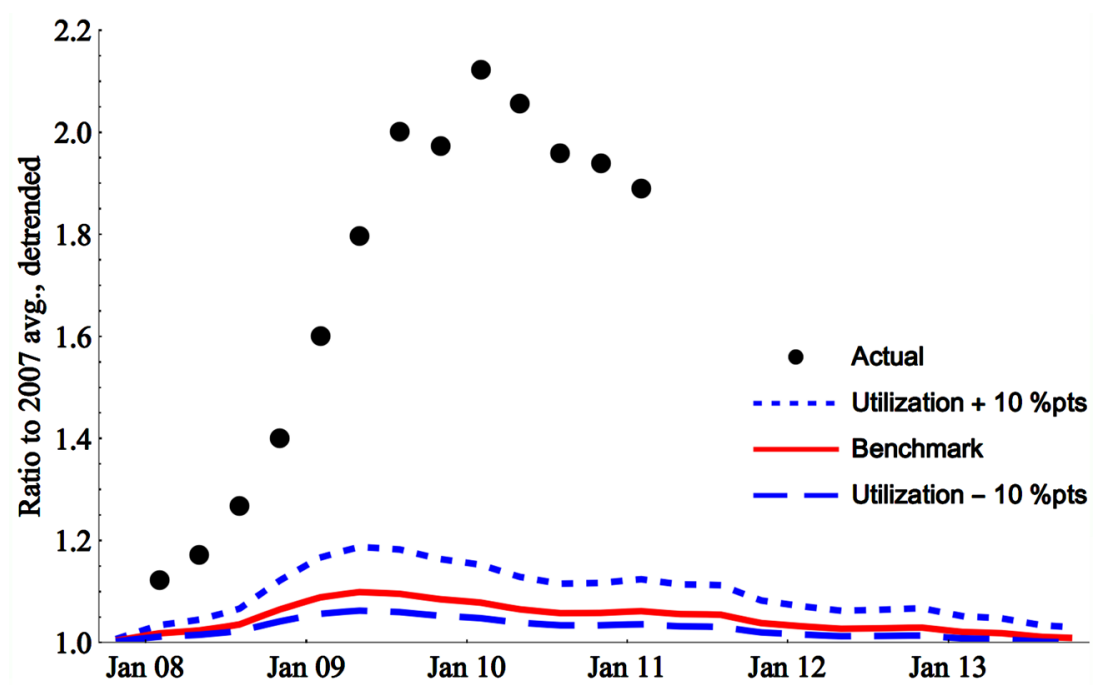

(c)

Figure 10. (a) Labor usage from the investment-distortion model; (b) Consumption from the investment-distortion model; (c) Subsidy expenditure from the investment-distortion model. 
Admittedly, Figure 6(e) shows deviations between the data and any one of the replacement rate scenarios. One possibility is that some of the measured investment decline was due to financial frictions. Or still other factors may explain part of the actual investment decline. For example, option value reasoning of [25] suggests that, to the extent that additional uncertainty about the efficient amount or composition of capital arose in 2008 and 2009, investment might have fallen even if labor had been constant. Investors may have anticipated an investment tax credit in 2010, and therefore saw investment in 2008 or 2009 as too expensive [26].

\section{Conclusions}

In the aggregate, subsidies flowing to the unemployed and to financially distressed households, in the forms of loan forgiveness and government transfers, more than doubled after 2007. Most of that increase cannot be explained by a mere increase in the number of people without jobs; most of it reflects increasing receipts per unemployed person. For example, unemployment benefits were extended and made more generous on multiple occasions after 2007, and the collapse of housing collateral values prevented lenders from fully collecting mortgage debts from borrowers who were unable to pay.

I estimate that, before the recession began, the combined receipts from Medicaid, unemployment insurance, SNAP, other means-tested government transfer programs, "home retention actions," and consumer loan charge-offs by commercial banks, on average replaced less than 17 percent of a prime-aged unemployed worker's marginal product. By 2010, the replacement rate was 29 percent. To the extent that the labor market is responsive to marginal tax rates, higher replacement rates reduce labor usage in the economy.

Using one of the simplest versions of the neoclassical growth model in which all parameters except the replacement rate are constant, this paper simulates competitive equilibrium responses to a tax rate (replacement plus explicit tax) that grew steadily during 2008 and 2009 from 25 to 37 percent. Assuming that the replacement rate would decline over the next several years (but not all of the way to its previous level), and assuming a Frisch wage elasticity of labor supply of 0.75 , the model's predictions for labor, consumption and productivity closely match the data from 2007 to the present.

The model also explains more than half of the actual investment decline as a response to the labor decline. Investment may be higher in the model than in the data for a couple of reasons: (a) consumption adjusts immediately in the model, whereas the actual consumption drop of 2008 took several months, and (b) actual productivity did grow during late 2008 and early 2009, but slightly below the trend assumed in the model. Because investment is a small fraction of total spending, these small deviations between model and data consumption and output create larger deviations between model and data investment.

Although my labor results for the aggregate of many means-tested programs 
are roughly in line with studies of unemployment benefits ${ }^{28}$, I cannot conclude that the entire labor decline after 2007 is the result of rising replacement rates, because the precise values for the replacement rate time series and the precise value for the labor supply elasticity could be somewhat different than are estimated and assumed in my benchmark parameterization. For example, my sensitivity analysis shows that a labor supply elasticity of $3 / 8$, rather than $3 / 4$, implies that a permanent tax rate increase from 25 to 37 percent (the series shown in green in Figure 6(a)) would reduce per capita labor usage by five percent by the end of 2009, or about half of the actual decline of nine percent. On the other hand, the available means-tested subsidies are not limited to the various subsidies that I combined for the purposes of estimating a replacement rate time series. Moreover, search frictions, rigid wages, and other labor market distortions could have many of the same effects as rising replacement rates.

Given that some of the means-tested transfers were expected to be temporary, the "Partial recovery" scenario shown in Figures 6(b)-6(f) suggests what people during the depths of the recession (e.g., late 2009) were expecting for the subsequent recovery of the various macroeconomic aggregates, without the benefit of hindsight that we now have. In particular, the green simulated series in Figure 6(b) and Figure 6(c) say that labor usage per capita would not recover to pre-recession levels, or even half way to pre-recession levels, at any time before 2014. Given a population growth rate of one percent per year, the aggregate hours index (private and public sectors combined) would not decline below its low of late 2009, but would not return to pre-recession levels until sometime in 2014. These expectations turned out to be correct, because actual aggregate labor usage did not surpass the 2007 levels until mid $2014^{29}$.

With continuing population and productivity growth, the model suggests that people expected real GDP to grow significantly after 2009, but that the recovery would be "jobless" in the sense that employment and hours per capita would not return to pre-recession levels for many years, and appear to be investment-driven in the sense that real GDP would grow faster than consumption through the end of 2013 (compare the green series in Figure 6(c) with the green series in Figure 6(e)).

A number of economists thought in 2010 and 2011 that the U.S. economy would enter a second recession as the provisions from the 2009 "stimulus law" expired $^{30}$. The model suggests the opposite: that the turning point for labor per capita would occur only when the marginal-tax-rate-increasing provisions of the stimulus law (or some other legislation) began to expire. In fact, the model and the data agree that labor per capita began to increase in early 2010, and return to

\footnotetext{
${ }^{28}$ About 40 percent of the increase shown in Figure 1 comes from unemployment benefits. Reference [11] concludes that emergency unemployment benefits "account for as much as 15 to 40 percent of the rise in aggregate unemployment duration," suggesting that (as a back-of-the-envelope estimate) the combination of programs shown in Figure 1 might account for as much as 38 to 100 percent of the reduction in labor.

${ }^{29}$ The first draft of this paper was written in 2009 (it can still be viewed at papers.nber.org) and therefore made these predictions without any benefit of hindsight.

${ }^{30}$ See, for example, [27], [28], and [29].
} 
previous levels only to the extent that replacement rates did.

In order to illustrate the explanatory power of a labor distortion, I assume that all other fundamentals stayed exactly on trend during this period (and will continue to do so) and have assumed highly stylized dynamics for the labor distortions. Reasonable people can debate whether these assumptions are approximately accurate, but certainly they are not literally true $\mathrm{e}^{31}$, and therefore even if the forecasts offered in my Figures 6(b)-(f) are reasonably accurate, they were not the best forecasts possible given information available during the recession. For example, total factor productivity growth was somewhat low prior to the recession, so as of 2008 one might have reasonably expected total factor productivity growth to be somewhat low at first, and then increase a bit with time. But, if this paper's emphasis on new and significant labor market distortions is correct, various other omitted factors would tend to be negligible at least in the near term.

\section{Acknowledgements}

I appreciate the comments on a predecessor of this paper by Andrei Shleifer, seminar participants at Clemson University, Tel Aviv University, students at M.I.T., and an anonymous referee.

\section{References}

[1] Ohanian, L.E. (2010) The Economic Crisis from a Neoclassical Perspective. Journal of Economic Perspectives, 24, 45-66. https://doi.org/10.1257/jep.24.4.45

[2] Barro, R.J. and King, R.G. (1984) Time Separable Preferences and Intertemporal Substitution Models of Business Cycles. Quarterly Journal of Economics, 99, 817839. https://doi.org/10.2307/1883127

[3] Shimer, R. (2010) Labor Markets and Business Cycles. Princeton University Press, Princeton. https://doi.org/10.1515/9781400835232

[4] Parkin, M. (1988) A Method for Determining Whether Parameters in Aggregative Models Are Structural. Carnegie-Rochester Conference Series on Public Policy, 29, 215-252. https://doi.org/10.1016/0167-2231(88)90014-0

[5] McGrattan, E.R. (1994) The Macroeconomic Effects of Distortionary Taxation. Journal of Monetary Economics, 33, 573-601.

https://doi.org/10.1016/0304-3932(94)90044-2

[6] Mulligan, C.B. (2012) The Redistribution Recession. Oxford University Press, New York. https://doi.org/10.1093/acprof:oso/9780199942213.001.0001

[7] Jermann, U.J. and Quadrini, V. (2012) Macroeconomic Effects of Financial Shocks. American Economic Review, 102, 238-271. https://doi.org/10.1257/aer.102.1.238

[8] Han, S. and Li, W.L. (2007) Fresh Start or Head Start? The Effects of Filing for Personal Bankruptcy on Work Effort. Journal of Financial Services Research, 31, 123 152. https://doi.org/10.1007/s10693-006-0001-0

[9] Gallen, T.S. (2015) Using Participant Behavior to Measure the Value of Social Pro-

${ }^{31}$ Reference [30] offers a methodology (not yet applied to the 2008-9 recession) which would account for all of the changes during a recession as the combination of several shocks in the neoclassical growth model. Because their method includes the same labor market condition (5) as mine, and the same definition of total factor productivity, we would agree that changes in the labor distortion during this recession were substantial and TFP changes minor. 
grams: The Case of Medicaid. Unpublished Manuscript, Purdue University.

[10] Meyer, B.D. (1990) Unemployment Insurance and Unemployment Spells. Econometrica, 58, 757-782. https://doi.org/10.2307/2938349

[11] Elsby, M.W.L., Hobijn, B. and Sahin, A. (2010) The Labor Market in the Great Recession. Brookings Papers on Economic Activity, 41, 1-69. https://doi.org/10.3386/w15979

[12] Mulligan, C.B. (2009) What Caused the Recession of 2008? Hints from Labor Productivity. NBER Working Paper, 14729. https://doi.org/10.3386/w14729

[13] Barro, R.J. and Sala-i-Martin, X. (2003) Economic Growth. M.I.T. Press, Cambridge.

[14] Mulligan, C.B. (2005) Public Policies as Specification Errors.Review of Economic Dynamics, 8, 902-926. https://doi.org/10.1016/j.red.2005.01.014

[15] Gali, J., Gertler, M. and Lopez-Salido, J.D. (2007) Markups, Gaps, and the Welfare Costs of Business Fluctuations. Review of Economics and Statistics, 89, 44-59. https://doi.org/10.1162/rest.89.1.44

[16] Hall, R.E. (1997) Macroeconomic Fluctuations and the Allocation of Time. Journal of Labor Economics, 15, S223-S250. https://doi.org/10.1086/209862

[17] Barro, R.J. and Sahasakul, C. (1983) Measuring the Average Marginal Tax Rate from the Individual Income Tax. Journal of Business, 56, 419-452. https://doi.org/10.1086/296211

[18] Mulligan, C.B. (2013) Recent Marginal Labor Income Tax Rate Changes by Skill and Marital Status. Tax Policy and the Economy, 27, 69-100. https://doi.org/10.1086/671244

[19] Mulligan, C.B. (2015) Side Effects and Complications: The Economic Consequences of Health-Care Reform. University of Chicago Press, Chicago. https://doi.org/10.7208/chicago/9780226285740.001.0001

[20] Mendoza, E.G., Razin, A. and Tesar, L.L. (1994) Effective Tax Rates in Macroeconomics: Cross Country Estimates of Tax Rates on Factor Incomes and Consumption. Journal of Monetary Economics, 34, 297-323. https://doi.org/10.1016/0304-3932(94)90021-3

[21] Prescott, E.C. (2004) Why Do Americans Work So Much More than Europeans? Federal Reserve Bank of Minneapolis Quarterly Review, 28, 2-14.

[22] Moffitt, R. (1983) An Economic Model of Welfare Stigma. American Economic Review, 73, 1023-1035.

[23] Lindbeck, A. (1995) Hazardous Welfare State Dynamics. American Economic Review, 85, 9-15.

[24] Mulligan, C.B. (2014) Uncertainty, Redistribution, and the Labor Market since 2007. IZA Journal of Labor Policy, 3, 1-16. https://doi.org/10.1186/2193-9004-3-8

[25] Abel, A.B., Dixit, A.K., Eberly, J.C. and Pindyck, R.S. (1996) Options, the Value of Capital, and Investment. Quarterly Journal of Economics, 111, 753-777. https://doi.org/10.2307/2946671

[26] Lucas Jr., R.E. (1976) Econometric Policy Evaluation: A Critique. Carnegie-Rochester Series on Public Policy, 1, 19-46. https://doi.org/10.1016/S0167-2231(76)80003-6

[27] Huff Post Business (2010) Nouriel Roubini: Double-Dip Odds Now Greater than $40 \%$, GDP To Be "Pathetically Lousy". http://www.huffingtonpost.com/2010/08/26/roubini_n_695536.html

[28] Krugman, P. (2011) The Wrong Worries. New York Times. 
[29] Norris, F. (2011) Time to Say It: Double Dip Recession May Be Happening. New York Times.

[30] Chari, V.V., Kehoe, P.J. and McGrattan, E.R. (2007) Business Cycle Accounting. Econometrica, 75, 781-836. https://doi.org/10.1111/j.1468-0262.2007.00768.x

[31] Mulligan, C.B. (2002) Capital, Interest, and Aggregate Intertemporal Substitution. NBER Working Paper, 9373. https://doi.org/10.3386/w9373

[32] Chetty, R., Guren, A., Manoli, D. and Weber, A. (2011) Are Micro and Macro Labor Supply Elasticities Consistent? A Review of Evidence on the Intensive and Extensive Margins. American Economic Review, 101, 1-6.

https://doi.org/10.1257/aer.101.3.471 


\section{Appendix I: Calibration and Simulation}

Aside from the replacement rate time path, the model has seven parameters to be calibrated (two of which are irrelevant for most of the calculations), as indicated in Table 1: labor's share $\alpha$, the adjusted depreciation rate $\delta$, the adjusted time preference rate $\rho$ and the wage elasticity of labor supply $\eta$, and the intertemporal consumption elasticity $\sigma$, prime labor's share of pre-recession labor income $1-\left[2+\left(\gamma_{m} / \gamma_{n}\right)^{\eta} / \beta^{\eta+1}\right]^{-1}$, and the amount $\Gamma$ of the prime labor time endowment ${ }^{32}$. Labor's share is taken as 0.7 , in order to coincide with measured values of the share of employee compensation in non-proprietor's private national income ${ }^{33}$.

The adjusted depreciation rate is taken as a pure depreciation rate minus population growth minus a trend for labor-augmenting technical change: the growth rate of gross investment expenditure on a balanced growth path. I use the value of $0.75 \%$ per year to reflect the likely possibility that, by 2008 , total-factorproductivity growth was expected to be positive, but less that it has been in the $1990 \mathrm{~s}$ and early $2000 \mathrm{~s}^{34}$. I also consider alternate values of $0.25 \% / \mathrm{yr}$ and $1.25 \% / \mathrm{yr}$.

Population growth is taken as 1.0 percent per year. The annual pure depreciation rate is taken as $5 \%$ plus $0.5 \%$, where the $5 \%$ is the ratio of private fixed asset depreciation per dollar of real private fixed assets in the national accounts. The model's investment is produced with the same technology as consumption goods, so it is best interpreted as investment expenditure deflated with the consumption deflator, and as such is expected to "depreciate" an additional amount according to the expected rate of decline of the real price of investment goods, which I take to be $0.5 \%$ per year. The benchmark adjusted depreciation rate is therefore $7.25 \% / \mathrm{yr}$, with alternative values of $6.75 \% / \mathrm{yr}$ and $7.75 \% / \mathrm{yr}$ depending on the alternative assumed value for expected TFP growth.

Prime labor's share of pre-recession labor income, which only matters for inferring total consumption expenditure $[c+(1-\tau) w \beta m]$ from market consumption expenditure $\mathcal{C}$, is assumed to be 0.9. The amount $\Gamma$ of the prime time endowment matters only for simulating the equilibrium size of the subsidy budget, and is taken to be 1.32 , because 76 percent $(=1 / 1.32)$ of persons aged 25 64 were employed during any given week in the years before the recession.

The "intertemporal consumption elasticity" is more precisely the elasticity of consumption growth with respect to the marginal product of capital. Some of the macroeconomics and consumption literature has assumed that this elasticity is necessarily the same as the elasticity of consumption growth with respect to the real return on safe short term loans, which in some models is closely related to the marginal product of capital. However, the asset pricing literature has

\footnotetext{
${ }^{32}$ Productivity and leisure preference are normalized so that low-replacement-rate steady-state labor and capital are one.

${ }^{33}$ Capital and labor income are not separately measured for proprietors, or in the public sector.

${ }^{34}$ With Cobb-Douglas production, labor-augmenting technical change is the same as TFP growth, except that the two are measured in different units (according to the labor exponent in production, $\alpha$ ).
} 
shown that the marginal product of capital and the risk free interest rate often change quite differently, so I stick with the more literal interpretation. Reference [31] finds an elasticity of consumption growth with respect to the (after-tax) marginal product of capital to be about 1.35 . This paper also reports sensitivity analysis using values ranging from $\sigma=0.5$ and $\sigma=2.0$.

The model's steady state ratio of consumption to output is $(\alpha \delta+\rho) /(\delta+\rho)$. I choose the rate of adjusted rate of time preference $\rho$ so that the consumption-output ratio is 73 percent as in the data. This implies that the benchmark $\rho$ is $0.5 \% / \mathrm{yr}$, with alternative values of $0.15 \% / \mathrm{yr}$ and $0.85 \% / \mathrm{yr}$ depending on the alternative assumed value for expected TFP growth.

My benchmark value for the labor elasticity is $0.75^{35}$. With this value, a two-year increase of the replacement rate by about 12 percentage points explains much of the labor decline over the first two years of the recession (see Figure 6(a) and Figure 6(b)). If the labor elasticity were assumed instead to be, say, 0.375 , then the same labor dynamics could be explained, but with a replacement rate that increases by about 24 percentage points instead of 12 . The red and green series in Figure A1(a) illustrate this point. The green series is simulated for the benchmark parameters (all series assume a "partial recovery" scenario for replacement rates), and the red series is for elasticities $\eta$ and $\sigma$ assumed to be half of their baseline values.

The smaller elasticities are consistent with a somewhat better recovery (Figures A1(a)-(c)) because more of the 2008 consumption drop can be inferred as consumption smoothing rather than expectations of relatively large replacement rates in the distant future.

Figure $\mathrm{A} 1(\mathrm{~b})$ and Figure $\mathrm{A} 1$ (c) show that results are more sensitive to assumptions about the trend for labor-augmenting technical change. The blue series are based on an assumed $1.25 \%$ annual trend, as compared to $0.25 \%$ for the black series and $0.75 \%$ for the benchmark. Greater TFP growth is consistent with greater replacement rates in the future because the 2008 consumption seems especially large when compared against TFP and population growth. Ultimately, higher TFP growth means more consumption and real GDP growth.

Time paths were simulated in three steps. First, the stable manifold for the stationary system having the long run replacement rate was calculated by numerically solving the ordinary differential equation in $k$ that is obtained by dividing $\dot{c}$ by $\dot{k}$ from the time-differential Equations (1) and (4). The ODE is evaluated at the long run replacement rate, using the corresponding steady state as the boundary condition. Second, I guessed a time $T$ point on the stable manifold for the stationary system having the long run replacement rate and numerically solved the dynamical system (1) and (4), which is non-stationary because the replacement rate varies with time, backwards in time until time zero ${ }^{36}$. I then

\footnotetext{
${ }^{35}$ In surveying the literature, [32] concludes that "Micro estimates imply a Frisch elasticity of aggregate hours of 0.78 " and "it would be reasonable to calibrate representative agent macro models to match a Frisch elasticity of aggregate hours of 0.75 " (recall that my parameter $\eta$ can be interpreted as the Frisch elasticity of aggregate hours).

${ }^{36} \mathrm{Time} T$ is the calendar time when the replacement rate stops changing.
} 


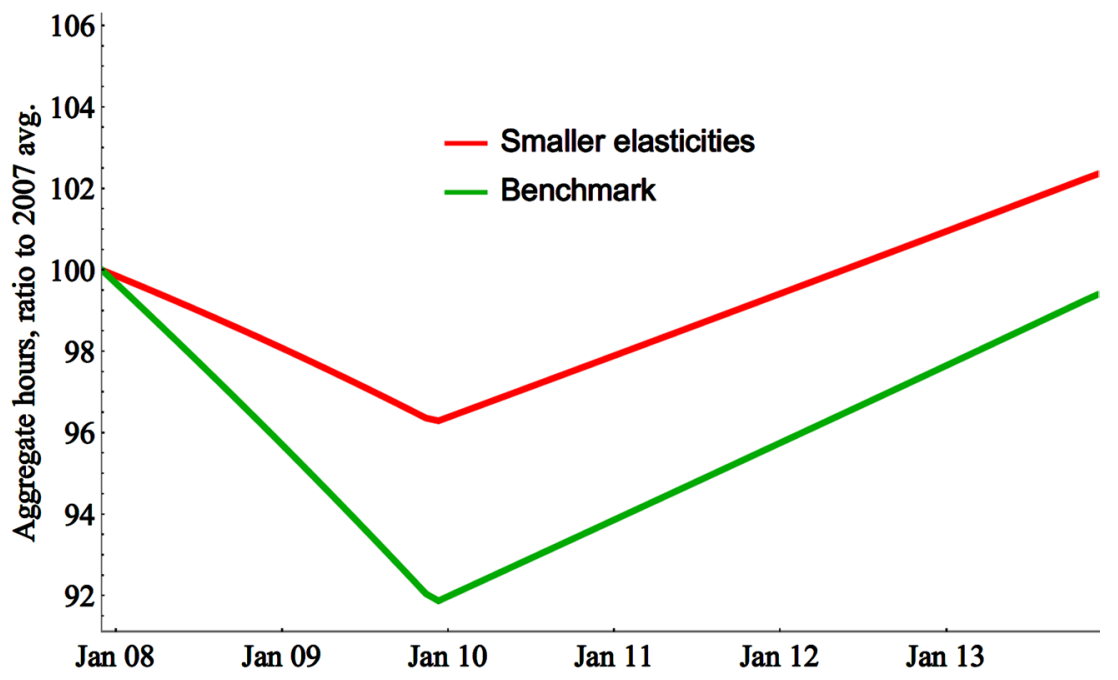

(a)

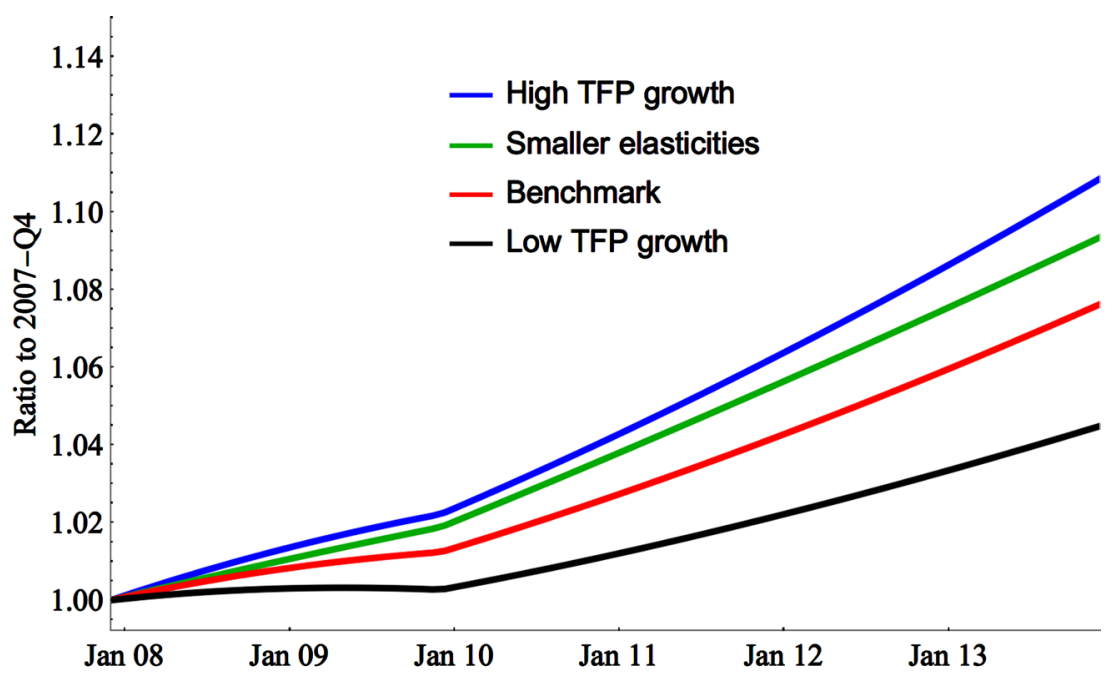

(b)

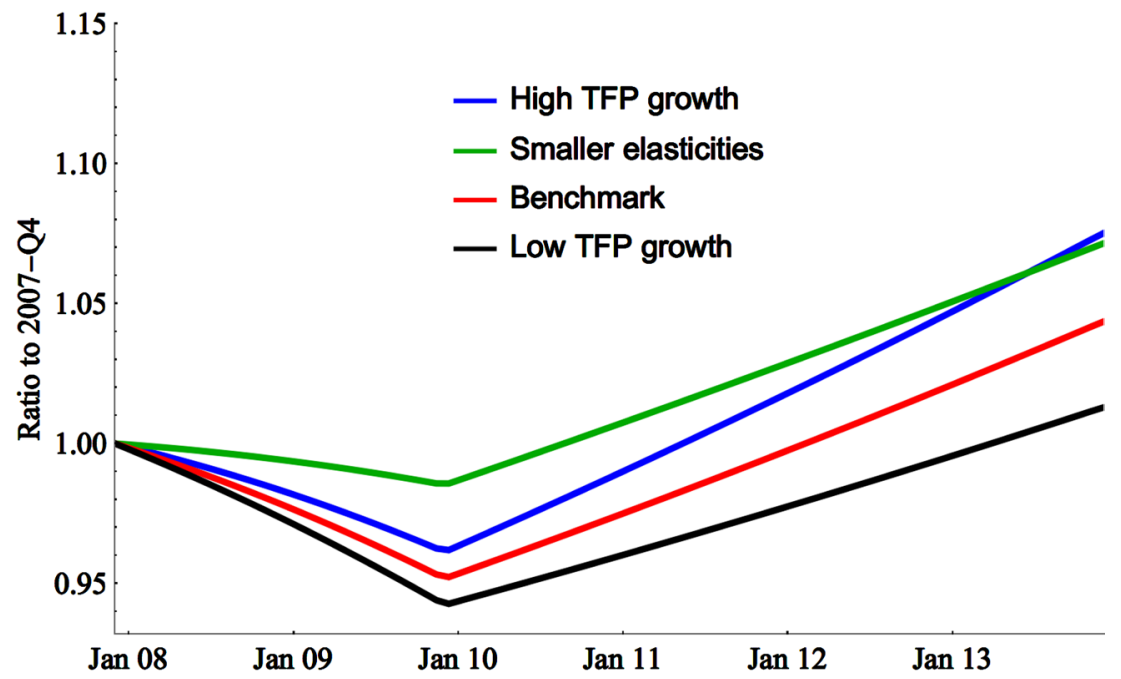

(c)

Figure A1. (a) Labor usage: sensitivity analysis; (b) Aggregate consumption: sensitivity analysis; (c) Aggregate output: sensitivity analysis. 
checked whether the capital stock at time zero corresponds with the assumed initial capital stock and, if not, repeated the procedure with a revised guess as to point on the stable manifold that would describe the economy at time $T$. Third, dynamics in the time dimension after time $T$ were simulated by numerically integrating the capital-accumulation Equation (1), imposing that consumption be on the stable manifold for the stationary system having the long run replacement rate $^{37}$. These simulations, and the Figure 4, Figure 6 and Figure 9, Figure 10, Figure A1 illustrating their results, were prepared in the Wolfram Language (Mathematica) and are available for download at http://www.nber.org/data-appendix/w17445/.

\section{Appendix II: Macroeconomic Data Sources}

The macroeconomic data used in this paper, displayed in Table A1 and Table A2, was sourced from the St. Louis Federal Reserve Bank's FRED database. The tables indicate the specific FRED series used.

Table A1. The monthly index of hours per adult.

\begin{tabular}{|c|c|c|c|c|c|}
\hline \multicolumn{6}{|c|}{ Constructed from FRED (St. Louis Federal Reserve) series } \\
\hline \multicolumn{6}{|c|}{ AWHAETP, PAYEMS, LNS12027714, LNS12032184, CNP16OV } \\
\hline Jan-2007 & 1.0010 & May-2009 & 0.9223 & Sep-2011 & 0.9225 \\
\hline Feb-2007 & 1.0006 & Jun-2009 & 0.9155 & Oct-2011 & 0.9243 \\
\hline Mar-2007 & 1.0046 & Jul-2009 & 0.9149 & Nov-2011 & 0.9249 \\
\hline Apr-2007 & 1.0027 & Aug-2009 & 0.9139 & Dec-2011 & 0.9268 \\
\hline May-2007 & 1.0026 & Sep-2009 & 0.9134 & Jan-2012 & 0.9257 \\
\hline Jun-2007 & 1.0052 & Oct-2009 & 0.9077 & Feb-2012 & 0.9247 \\
\hline Jul-2007 & 1.0005 & Nov-2009 & 0.9108 & Mar-2012 & 0.9260 \\
\hline Aug-2007 & 0.9974 & Dec-2009 & 0.9088 & Apr-2012 & 0.9258 \\
\hline Sep-2007 & 0.9983 & Jan-2010 & 0.9114 & May-2012 & 0.9217 \\
\hline Oct-2007 & 0.9940 & Feb-2010 & 0.9064 & Jun-2012 & 0.9249 \\
\hline Nov-2007 & 0.9966 & Mar-2010 & 0.9112 & Jul-2012 & 0.9250 \\
\hline Dec-2007 & 0.9965 & Apr-2010 & 0.9151 & Aug-2012 & 0.9242 \\
\hline Jan-2008 & 0.9990 & May-2010 & 0.9173 & Sep-2012 & 0.9255 \\
\hline Feb-2008 & 0.9980 & Jun-2010 & 0.9150 & Oct-2012 & 0.9253 \\
\hline Mar-2008 & 0.9959 & Jul-2010 & 0.9162 & Nov-2012 & 0.9259 \\
\hline Apr-2008 & 0.9908 & Aug-2010 & 0.9147 & Dec-2012 & 0.9295 \\
\hline May-2008 & 0.9915 & Sep-2010 & 0.9161 & Jan-2013 & 0.9252 \\
\hline Jun-2008 & 0.9900 & Oct-2010 & 0.9185 & Feb-2013 & 0.9288 \\
\hline Jul-2008 & 0.9861 & Nov-2010 & 0.9144 & Mar-2013 & 0.9265 \\
\hline Aug-2008 & 0.9816 & Dec-2010 & 0.9171 & Apr-2013 & 0.9265 \\
\hline Sep-2008 & 0.9742 & Jan-2011 & 0.9165 & May-2013 & 0.9278 \\
\hline Oct-2008 & 0.9681 & Feb-2011 & 0.9191 & Jun-2013 & 0.9311 \\
\hline Nov-2008 & 0.9586 & Mar-2011 & 0.9205 & Jul-2013 & 0.9303 \\
\hline Dec-2008 & 0.9486 & Apr-2011 & 0.9234 & Aug-2013 & 0.9328 \\
\hline Jan-2009 & 0.9464 & May-2011 & 0.9239 & Sep-2013 & 0.9298 \\
\hline Feb-2009 & 0.9447 & Jun-2011 & 0.9211 & Oct-2013 & 0.9294 \\
\hline Mar-2009 & 0.9314 & Jul-2011 & 0.9233 & Nov-2013 & 0.9326 \\
\hline Apr-2009 & 0.9258 & Aug-2011 & 0.9216 & Dec-2013 & 0.9280 \\
\hline
\end{tabular}

${ }^{37}$ Note that all three steps describe simulations of the nonlinear system (1) and (4), rather than linear approximations to it. 
Table A2. Quarterly macroeconomic aggregates.

\begin{tabular}{|c|c|c|c|c|c|}
\hline $\begin{array}{l}\text { Quarter } \\
\text { beginning }\end{array}$ & $\begin{array}{l}\text { Cons. quantity } \\
\text { index Figure 6(c) }\end{array}$ & $\begin{array}{l}\text { Popul. (1000s) } \\
\text { Figure 6(c) and Figure 6(e) }\end{array}$ & $\begin{array}{l}\text { Labor productivity } \\
\text { index Figure } 6(d)\end{array}$ & $\begin{array}{l}\text { Investment quantity } \\
\text { index Figure } 6(\mathrm{e})\end{array}$ & $\begin{array}{l}\text { Investment quantity index, } \\
\text { w/o housing Figure } 6(\mathrm{e})\end{array}$ \\
\hline Jan-2007 & 0.9964 & 300,610 & 0.9952 & 0.9929 & 0.9750 \\
\hline Apr-2007 & 0.9985 & 301,284 & 0.9968 & 1.0063 & 0.9993 \\
\hline Jul-2007 & 1.0018 & 302,063 & 1.0032 & 1.0057 & 1.0114 \\
\hline Oct-2007 & 1.0033 & 302,829 & 1.0048 & 0.9951 & 1.0143 \\
\hline Jan-2008 & 1.0048 & 303,494 & 0.9947 & 0.9662 & 0.9934 \\
\hline Apr-2008 & 1.0070 & 304,160 & 1.0021 & 0.9563 & 0.9885 \\
\hline Jul-2008 & 1.0042 & 304,902 & 1.0027 & 0.9325 & 0.9675 \\
\hline Oct-2008 & 1.0017 & 305,617 & 0.9994 & 0.8623 & 0.8976 \\
\hline Jan-2009 & 1.0003 & 306,237 & 1.0016 & 0.8030 & 0.8393 \\
\hline Apr-2009 & 0.9984 & 306,866 & 1.0174 & 0.7756 & 0.8135 \\
\hline Jul-2009 & 0.9993 & 307,573 & 1.0240 & 0.7835 & 0.8177 \\
\hline Oct-2009 & 1.0014 & 308,285 & 1.0347 & 0.8112 & 0.8504 \\
\hline Jan-2010 & 1.0040 & 308,902 & 1.0355 & 0.8276 & 0.8734 \\
\hline Apr-2010 & 1.0084 & 309,473 & 1.0343 & 0.8622 & 0.9087 \\
\hline Jul-2010 & 1.0111 & 310,099 & 1.0369 & 0.8828 & 0.9430 \\
\hline Oct-2010 & 1.0163 & 310,731 & 1.0377 & 0.8835 & 0.9419 \\
\hline Jan-2011 & 1.0179 & 311,253 & 1.0288 & 0.8750 & 0.9320 \\
\hline Apr-2011 & 1.0195 & 311,781 & 1.0278 & 0.8913 & 0.9499 \\
\hline Jul-2011 & 1.0205 & 312,407 & 1.0260 & 0.8951 & 0.9523 \\
\hline Oct-2011 & 1.0219 & 313,016 & 1.0300 & 0.9396 & 1.0021 \\
\hline Jan-2012 & 1.0251 & 313,530 & 1.0262 & 0.9578 & 1.0167 \\
\hline Apr-2012 & 1.0258 & 314,048 & 1.0283 & 0.9733 & 1.0339 \\
\hline Jul-2012 & 1.0265 & 314,661 & 1.0243 & 0.9739 & 1.0315 \\
\hline Oct-2012 & 1.0267 & 315,269 & 1.0178 & 0.9726 & 1.0237 \\
\hline Jan-2013 & 1.0285 & 315,734 & 1.0203 & 0.9974 & 1.0485 \\
\hline Apr-2013 & 1.0295 & 316,225 & 1.0164 & 1.0063 & 1.0552 \\
\hline Jul-2013 & 1.0328 & 316,843 & 1.0171 & 1.0290 & 1.0801 \\
\hline Oct-2013 & 1.0388 & 317,474 & 1.0236 & 1.0400 & 1.0949 \\
\hline FRED & PCND & POPTHM & GDPC1 & PCDG & PCDG \\
\hline component & PCESV & & AWHAETP & GPDI & GPDI \\
\hline \multirow[t]{9}{*}{ series } & PCNDGC96 & & PAYEMS & PCDGCC96 & PCDGCC96 \\
\hline & PCESVC96 & & LNS12027714 & GPDIC96 & GPDIC96 \\
\hline & A955RC1Q027SBEA & & LNS12032184 & A782RC1Q027SBEA & A782RC1Q027SBEA \\
\hline & A997RC1Q027SBEA & & & Y050RC1Q027SBEA & Y050RC1Q027SBEA \\
\hline & A955RA3Q086SBEA & & & A808RC1Q027SBEA & A808RC1Q027SBEA \\
\hline & A997RA3Q086SBEA & & & Y052RC1Q027SBEA & Y052RC1Q027SBEA \\
\hline & & & & A782RA3Q086SBEA & A782RA3Q086SBEA \\
\hline & & & & B788RA3Q086SBEA & B788RA3Q086SBEA \\
\hline & & & & & PRFI, PRFIC96 \\
\hline
\end{tabular}


Submit or recommend next manuscript to SCIRP and we will provide best service for you:

Accepting pre-submission inquiries through Email, Facebook, LinkedIn, Twitter, etc. A wide selection of journals (inclusive of 9 subjects, more than 200 journals)

Providing 24-hour high-quality service

User-friendly online submission system

Fair and swift peer-review system

Efficient typesetting and proofreading procedure

Display of the result of downloads and visits, as well as the number of cited articles Maximum dissemination of your research work

Submit your manuscript at: http://papersubmission.scirp.org/

Or contact jmf@scirp.org 